\title{
Myxosporean plasmodial infection associated with ulcerative lesions in young-of-the-year Atlantic menhaden in a tributary of the Chesapeake Bay, and possible links to Kudoa clupeidae
}

\author{
R. Reimschuessel ${ }^{1, *}$, C. M. Gieseker ${ }^{1,2}$, C. Driscoll ${ }^{2}$, A. Baya ${ }^{3}$, A. S. Kane ${ }^{4}$, \\ V. S. Blazer ${ }^{5}$, J. J. Evans ${ }^{6}$, M. L. Kent ${ }^{7}$, J. D. W. Moran ${ }^{8}$, S. L. Poynton ${ }^{9,10}$ \\ ${ }^{1}$ US Food and Drug Administration, Center for Veterinary Medicine, Office of Research, Laurel, Maryland 20708, USA \\ ${ }^{2}$ Maryland Dept of Natural Resources, Cooperative Oxford Laboratory, Oxford, Maryland 21654, USA \\ ${ }^{3}$ Virginia-Maryland Regional College of Veterinary Medicine, University of Maryland, College Park, Maryland 20740, USA \\ ${ }^{4}$ Aquatic Pathobiology Center, University of Maryland, Dept of Veterinary Medicine, College Park, Maryland 20742, USA \\ ${ }^{5}$ US Geological Survey, National Fish Health Research Laboratory, Kearneysville, West Virginia 25430, USA \\ ${ }^{6}$ US Dept of Agriculture, Agriculture Research Service, Aquatic Animal Health Research Lab, Chestertown, Maryland 21620, USA \\ ${ }^{7}$ Center for Fish Disease Research, Dept of Microbiology, Oregon State University, Corvallis, Oregon 97331, USA \\ ${ }^{8}$ School of Veterinary Medicine, University of California, 1 Shields Avenue, Davis, California 95616, USA \\ ${ }^{9}$ Johns Hopkins University School of Medicine, Dept of Comparative Medicine, Baltimore, Maryland 21287, USA \\ ${ }^{10}$ Institut für Gewässerökologie und Binnenfischerei, Müggelseedamm 310, Friederichshagen, 12587 Berlin, Germany
}

\begin{abstract}
Ulcers in Atlantic menhaden Brevoortia tyrannus (Latrobe) (Clupeidae), observed along the USA east coast, have been attributed to diverse etiologies including bacterial, fungal and, recently, harmful algal blooms. To understand the early pathogenesis of these lesions, we examined juvenile Atlantic menhaden collected during their seasonal presence in Chesapeake Bay tributaries from April to October 1999 and from March to August 2000. We conducted histopathological examinations of young-of-the-year fish from the Pocomoke River tributary, which has a history of fish mortalities and high lesion prevalence. Kudoa clupeidae (Myxozoa: Myxosporea) spores were present in the muscles of fish collected in both years. Of the fish assessed by histology in April, 5 to $14 \%$ were infected, while in May 90 to $96 \%$ were infected. Infection rates remained high during the summer. Mature spores were primarily located within myomeres and caused little or no observable pathological changes. Ultrastructure showed spores with capsulogenic cells bearing filamentous projections, and a basal crescentic nucleus with mottled nucleoplasm containing cleaved, condensed chromatin. Also, a highly invasive plasmodial stage of a myxozoan was found in the lesions of juvenile Atlantic menhaden. The plasmodia were observed in fish collected between May and July, with the maximum occurrence in late June 1999 and late May 2000. Plasmodia penetrated and surrounded muscle bundles, causing grossly observable raised lesions in $73 \%$ of all fish infected with this invasive stage. Plasmodia were also detected in the visceral organs, branchial arches, and interocular muscles of some fish. Some of the invasive extrasporogonic plasmodial lesions were associated with ulcers and chronic inflammatory infiltrates. The plasmodial stage appeared to slough out of the tissue with subsequent evidence of wound healing. Ultrastructure showed plasmodia with an elaborate irregular surface, divided into distinct ectoplasm and endoplasm; the latter contained numerous spherical vegetative nuclei, secondary generative cells, and occasional cell doublets. Our ultrastructural studies indicate that the plasmodial organisms, which are important in the etiology of the skin lesions, are myxozoans, and they may represent early stages of K. clupeidae.
\end{abstract}

KEY WORDS: Atlantic menhaden $\cdot$ Brevoortia tyrannus $\cdot$ Kudoa clupeidae $\cdot$ Myxosporea $\cdot$ Plasmodia Lesions 


\section{INTRODUCTION}

Skin lesions in wild fishes have been attributed to numerous etiologies, including viral, fungal, bacterial, and parasitic infections (Sindermann 1988, Marty et al. 1998). Ulcers have been observed in Atlantic menhaden Brevoortia tyrannus (Clupeidae) along the east coast of the USA, primarily from North Carolina to Maryland, for many years (Dykstra et al. 1989, Levine et al. 1990a,b, Kane et al. 1998). Cultures of ulcers from wild fishes have yielded fungi (Dykstra et al. 1986, Noga \& Dykstra 1986, Levine et al. 1990b, Blazer et al. 1999) and various bacteria (Te Strake \& Lim 1987, Dykstra et al. 1989, Baya et al. 1990, 1997). Recently, some investigators have proposed a causal relationship between harmful algal bloom fish mortalities, such as those caused by Pfiesteria piscicida, and the presence of ulcers on Atlantic menhaden (Noga et al. 1996, Burkholder \& Glasgow 1997, Noga 2000). Furthermore, the Centers for Disease Control and Prevention (CDC) have used the occurrence of ulcerative lesions in Atlantic menhaden as evidence of suspected toxins associated with harmful algal blooms (CDC 1997). Although this proposed relationship has been widely publicized, particularly since the mass mortality episodes of 1997 in Maryland, it is important to note that not all mass mortalities of fishes associated with harmful algal blooms have had fish with skin lesions present. Conversely, not all fish-lesion epizootics are associated with algal blooms (Sindermann 1988, Schäperclaus 1991, Baya et al. 1997, Lilley et al. 1998). The early pathogenesis of these chronic lesions in Atlantic menhaden remains an active area of investigation.

Atlantic menhaden play an important role in coastal marine and estuarine systems, both as filter feeders of plankton and as a primary prey species of piscivorous fishes, and support one of the most established commercial fisheries in the US (Rogers \& van den Avyle 1989, Smith 1991, 1999). Atlantic menhaden are reduced to meal, oil and condensed solids, which are used in animal feeds and industrial products (Hale et al. 1991). In 1997, the US Food and Drug Administration classified menhaden oil as 'generally recognized as safe' for use in human food (US Food \& Drug Administration 1997). This designation has opened new US markets for the use of menhaden oil in human food items (such as cooking oil, shortening, margarine), an already common practice in Europe (Hale et al. 1991).

Previous studies of lesions in Atlantic menhaden from North Carolina and in the Chesapeake Bay from Virginia and Maryland have focused on fish greater than $70 \mathrm{~mm}$ fork length (Noga \& Dykstra 1986, Kane et al. 1998, 2000, Blazer et al. 1999). Histological exami- nation of these lesions has shown that they are chronic, and the majority can be characterized as ulcerative mycosis (Noga \& Dykstra 1986, Kane et al. 1998, Blazer et al. 1999). Recently, the fungal agent associated with ulcerative mycosis in Atlantic menhaden has been identified as Aphanomyces invadans (Blazer et al. 2002). Lesions identical to those observed in the wild have been reproduced by injection and bath exposure to fungal zoospores (Kiryu et al. 2003). Similar lesions have been described in other endemic ulcerative diseases in fishes around the world (Sindermann 1988, Lilley et al. 1998).

To better understand the early pathogenesis of ulcerative lesions in Atlantic menhaden from the Chesapeake Bay, we examined young-of-the-year Atlantic menhaden collected from the Pocomoke River, which has a history of fish mortalities and high lesion prevalence. We now present the first published report of lesions associated with developing myxosporean parasites in the early life stages of Atlantic menhaden.

\section{MATERIALS AND METHODS}

Fish collection. Atlantic menhaden Brevoortia tyrannus (Latrobe) were collected by surface trawl, seine, or cast net from April to October 1999 and from March to August 2000 in the Pocomoke River, Maryland. The Pocomoke River was selected for study because of its history of fish mortalities and high lesion prevalence in Atlantic menhaden during the summer of 1997. Samples were collected every other week in 1999 and weekly in 2000. Sample sizes varied due to the daily and seasonal variations in Atlantic menhaden distribution in the river. Fork lengths ranged from a mean of 34 (32 to 43) $\mathrm{mm}$ in March to 96 (88 to 97) $\mathrm{mm}$ in September.

Gross and histological examination. Fish were examined in the field for the presence of observable lesions on the body surface. Whenever possible, a total of 10 fish (both with and without observable lesions) per collection date were preserved for histological examination. Fish less than $20 \mathrm{~mm}$ fork length were preserved whole, while larger fish were opened and the abdominal wall removed prior to fixation in $10 \%$ neutral buffered formalin. Tissue samples were processed for routine histopathology (Prophet et al. 1992), and sections (5 to $6 \mu \mathrm{m}$ ) were stained with hematoxylin and eosin (H\&E). To demonstrate the polar capsules of the myxosporean spores, sections were stained with Grocott's methenamine silver (GMS), acid-fast Gram (Brown \& Hopps) stain (Prophet et al. 1992), periodic acid Schiff, Alcian blue (pH 2.5) (Carson 1990), Giemsa (May-Grunwald), Feulgen reaction, and Protargol silver protein stain (Bodian's method; Sheehan \& Hrapchak 1980). 
In May 1999, an additional 10 fish were collected for examination of the somatic musculature using wetmount preparations and light microscopy. Measurements of 10 fresh myxosporean spores were made using a calibrated ocular micrometer according to the recommendations of Lom \& Arthur (1989).

Electron microscopy. To visualize fine details of external spore morphology and facilitate species identification, spores were examined using scanning electron microscopy (SEM). Spores were obtained from fish frozen on dry ice. Epaxial muscles having no gross lesions were removed from the body, thawed on a glass slide, and viewed under a light microscope. Regions having spores were identified and placed into $2.5 \%$ glutaraldehyde with $0.4 \mathrm{M}$ Millonig's phosphate buffer (pH 7.6) and 1.0 M NaCl (Cloney \& Florey 1968, Dungan \& Elston 1988) for $48 \mathrm{~h}$. Tissues were washed in a sucrose buffer $(0.2 \mathrm{M}$ sucrose in $0.1 \mathrm{M}$ sodiumcacodylate) and fixed in $1 \%$ osmium tetroxide $\left(\mathrm{OsO}_{4}\right)$ (Bennett \& Luft 1959) for $30 \mathrm{~min}$. Tissues were then washed 5 times in deionized water and placed in a saturated solution of thiocarbohydrazide for $20 \mathrm{~min}$. Tissues were subsquently washed in deionized water $(5 \times$ $2 \mathrm{~min}$ ), placed in fresh $1 \% \mathrm{OsO}_{4}$ for $30 \mathrm{~min}$, and washed again in deionized water $(5 \times 2 \mathrm{~min})$. Samples were then dehydrated in a graded ethanol (EtOH) series $70 \%$ for $10 \mathrm{~min}, 95 \%$ for $10 \mathrm{~min}, 100 \% 4 \times$ $10 \mathrm{~min}$ ). Tissues were dried to critical point (Samdri790B, Tousimis Research), mounted on aluminum stubs (Electron Microscopy Sciences), and coated with gold (Hummer Technics). Specimens were observed using an AMR-1000 SEM (Advanced Metals Research).

To investigate the ultrastructure of the extrasporogonic plasmodia, lesion tissues were prepared for trans- mission electron microscopy (TEM). Tissues were fixed in $2.5 \%$ glutaraldehyde with $0.4 \mathrm{M}$ Millonig's phosphate buffer ( $\mathrm{pH} 7.6$ ) and $1.0 \mathrm{M} \mathrm{NaCl}$ (Cloney \& Florey 1968, Dungan \& Elston 1988) for 48 h. After fixation, tissues were trimmed, washed in Millonig's phosphate

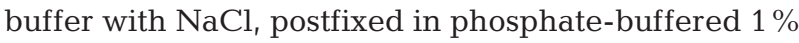
$\mathrm{OsO}_{4}$ for $1 \mathrm{~h}$ at $20^{\circ} \mathrm{C}$ (Bennett \& Luft 1959), rinsed with nanopure water, and dehydrated through 35,50 , and $70 \%$ EtOH. Tissues were then stained en bloc with uranyl acetate (Huxley \& Zubay 1961, Farquhar \& Palade 1965). The specimens were dehydrated in $100 \% \mathrm{EtOH}$ and embedded in Epon (Luft 1961, Trump et al. 1961). Toluidine blue-stained $1 \mu \mathrm{m}$ thick sections were observed by high-resolution light microscopy, and ultrathin sections were stained with lead citrate (Venable \& Coggeshall 1965) and examined using a JEOL-1200EX, TEM (JEOL USA).

\section{RESULTS}

\section{Skin lesions: gross appearance and occurrence}

Skin lesions were observed on menhaden as small as $40 \mathrm{~mm}$. The lesions, typically 1 per fish, consisted of either raised or ulcerated reddish-pink areas 3 to $5 \mathrm{~mm}$ in diameter, and were located on all body regions, including head, operculum, body wall and caudal peduncle (Fig. 1A-D). In some cases, the lesions were located deeper within the musculature, but remained visible through the muscles and epithelium.

In 1999, fish with lesions were found during a $6 \mathrm{wk}$ period from late May until early July. In 2000, the lesions occurred for approximately $4 \mathrm{wk}$, from early May to early June. In 2000, a second occurrence of
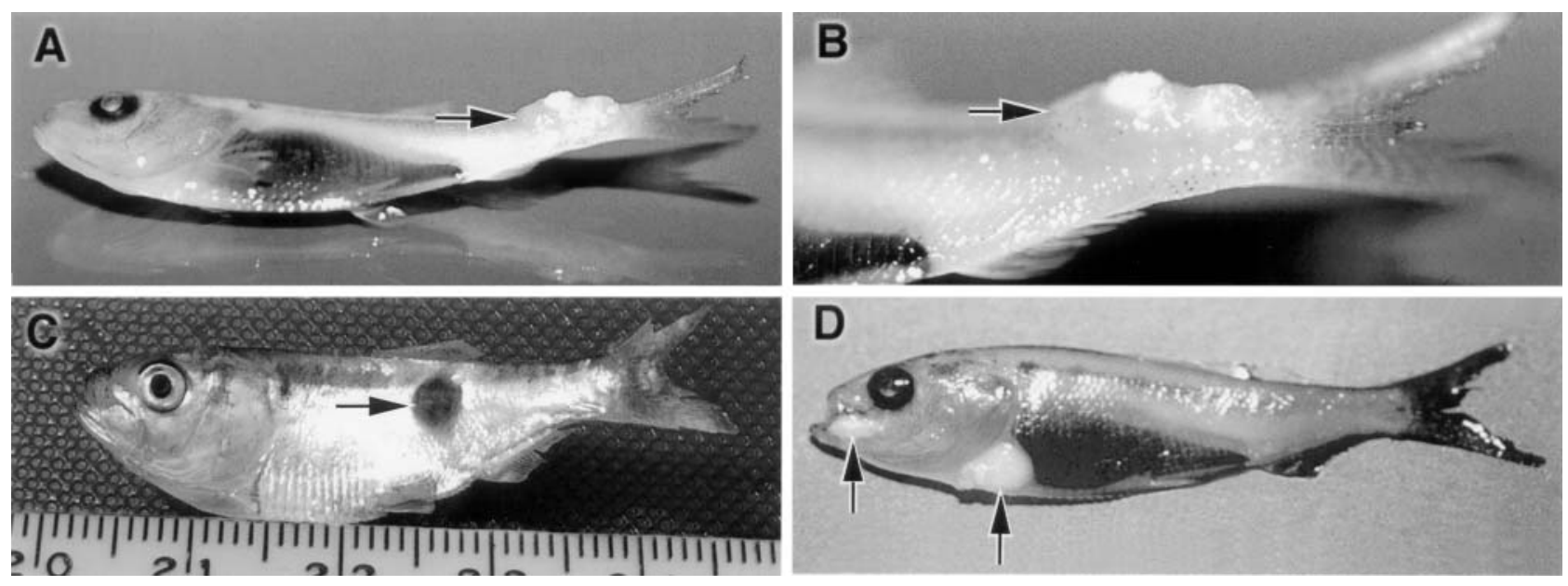

Fig. 1. Brevoortia tyrannus. Juvenile Atlantic menhaden with gross lesions (arrows). All lesions shown here were reddish-pink, raised, and ulcerated when sampled. Following fixation, lesions appeared white. (A), (B) and (D) preserved in formalin; (C) fresh specimen 
lesions was observed from mid-July to August. The latter lesions were subsequently confirmed by histopathology as ulcerative mycosis similar to those described by Noga \& Dykstra (1986), Kane et al. (1998), and Blazer et al. (1999).

\section{Spores: morphology and ultrastructure}

Myxosporean spores were present in impression smears of skin lesions and epaxial muscle. The spores were rounded quadrates in apical view, with 4 equalsized pyriform polar capsules (Fig. 2A,B). In lateral view, the spores were a flattened ovoid, and narrowed apically to a cone-shaped projection; the anteriolateral tips of the spores' valves were slightly uplifted, but were shorter than the central cone-shaped projection (Fig. 2C). In wet-mount preparations, measurements from 10 spores were on average 5.25 (5.0 to 5.5) $\mu \mathrm{m}$ long, $6.5 \mu \mathrm{m}$ wide, and 6 (5.5 to 6.5 ) $\mu \mathrm{m}$ thick; the polar capsules measured 1.4 (1.3 to 1.5$) \mu \mathrm{m} \times 1.0$ $\mu \mathrm{m}$. Polar capsules appeared dark fuscia pink in wetmount preparations stained with Ziehl-Neelsen acidfast stain.

Scanning electron microscopy showed that the spore comprised 4 equal-sized valves, with slight constrictions between them. The valves were delineated by straight, unadorned sutures (Fig. 2D-G). At the base of the spore, only 2 of the 4 valves met (Fig. 2E). In lateral view, the spore sloped gradually from the apex to the apicolateral regions, then curved gently to a flattened and rounded base (Fig. 2G). The spore resembled a plump cushion when viewed from beneath (Fig. 2E). Apical and lateral views showed 2 different types of ornamentations arising from the spore surface. Each valve bore an apical projection 0.6 $\mu \mathrm{m}$ long, and the apposition of all 4 apical projections produced the central attenuated conical projection seen by light microscopy. The uplifted anterio-lateral tips of each valve varied in size and shape, usually becoming wider towards the apical surface of the spore and terminating in a rounded tip. In some spores, the tips of each valve appeared fin-like when viewed laterally, with the long axis of the fin running in the same direction as the sutures (Fig. 2G). In other spores, the uplifted tips of each valve were more breast-like (Fig. 2F). The ornamentations that projected from the spore surface appeared to be made of the same material as the remainder of the spore valve, and the entire surface of the spore was smooth. The spores were identified as Kudoa clupeidae (Myxozoa: Myxosporea) (see 'Discussion').

Transmission electron microscopy (TEM) showed that the apical projections of the spore (Fig. 3A,B) were supported by microtubules (Fig. 3C); however, such support was not visible in the remainder of the valves, including the uplifted anterio-lateral tips (Fig. 4A,B). The apical part of the Kudoa clupeidae spore contained the 4 capsulogenic cells, each of which was dominated by a polar capsule, with a wall which consisted of an outer electron dense layer 0.05 to $0.08 \mu \mathrm{m}$ thick and an inner electron-lucent layer 0.14 to $0.24 \mu \mathrm{m}$ thick (Fig. 4A,B). The capsule contained electrondense material within which lay the inverted polar filament coil with 2 to 3 turns (Fig. 3B). Around the base of the polar capsule lay a crescent-shaped area of mottled nucleoplasm (Fig. 3B) and a moderately electrondense cleaved, tri-lobed structure (Fig. 3A: ne), subsequently identified as condensed chromatin (see Fig. 5E). The most remarkable feature of the capsulogenic cells was their surface, which was covered by numerous $0.05 \mu \mathrm{m}$ wide, branching filamentous projections (Fig. 4A,B). The basal part of the K. clupeidae spore contained the sporoplasm, which consisted of 2 cells, one lying within the other (Fig. 3A,B). The nuclei (n) of the sporoplasm were irregular, amoeboid in shape, with heterogeneous (frequently peripheral) chromatin. The cytoplasm of the inner spherical sporoplasmic cell was densely granular with relatively few inclusions, whereas that of the outer crescent-shaped sporoplasmic cell was more heterogeneous, with some less dense granular areas and numerous inclusions. Capsulogenic and sporoplasmic cells contained mitochondria.

Surrounding some spores was a fragmenting plasmodium, the surface of which had regions of irregular, branched, pedunculated, and fused extensions (Fig. 3A). However, only 2 such foci were examined by TEM.

\section{Spores: histopathology}

Numerous mature Kudoa clupeidae spores were present in the midline branchial, interocular, and lateral body musculature (Fig. 5A). Spores were usually found within myomeres causing little to no host response or tissue pathology (Fig. 5B). Some myomeres were greatly enlarged by the spores, becoming distended and compressing surrounding myomeres. Primarily, mature spores were found in the distended myomere, although, occasionally, cells lining the edge of the spore plasmodium appeared to be at an earlier developmental stage. Some spores were located between myomeres, presumably released from ruptured myomeres (Fig. 5C). Polar capsules were clearly demonstrated with Gram stain (Fig. 5D) and GMS, but not with acid-fast stain. The PAS stain outlined the polar capsules and showed intensely staining spherical material at the base of each polar capsule (Fig. 5E). 

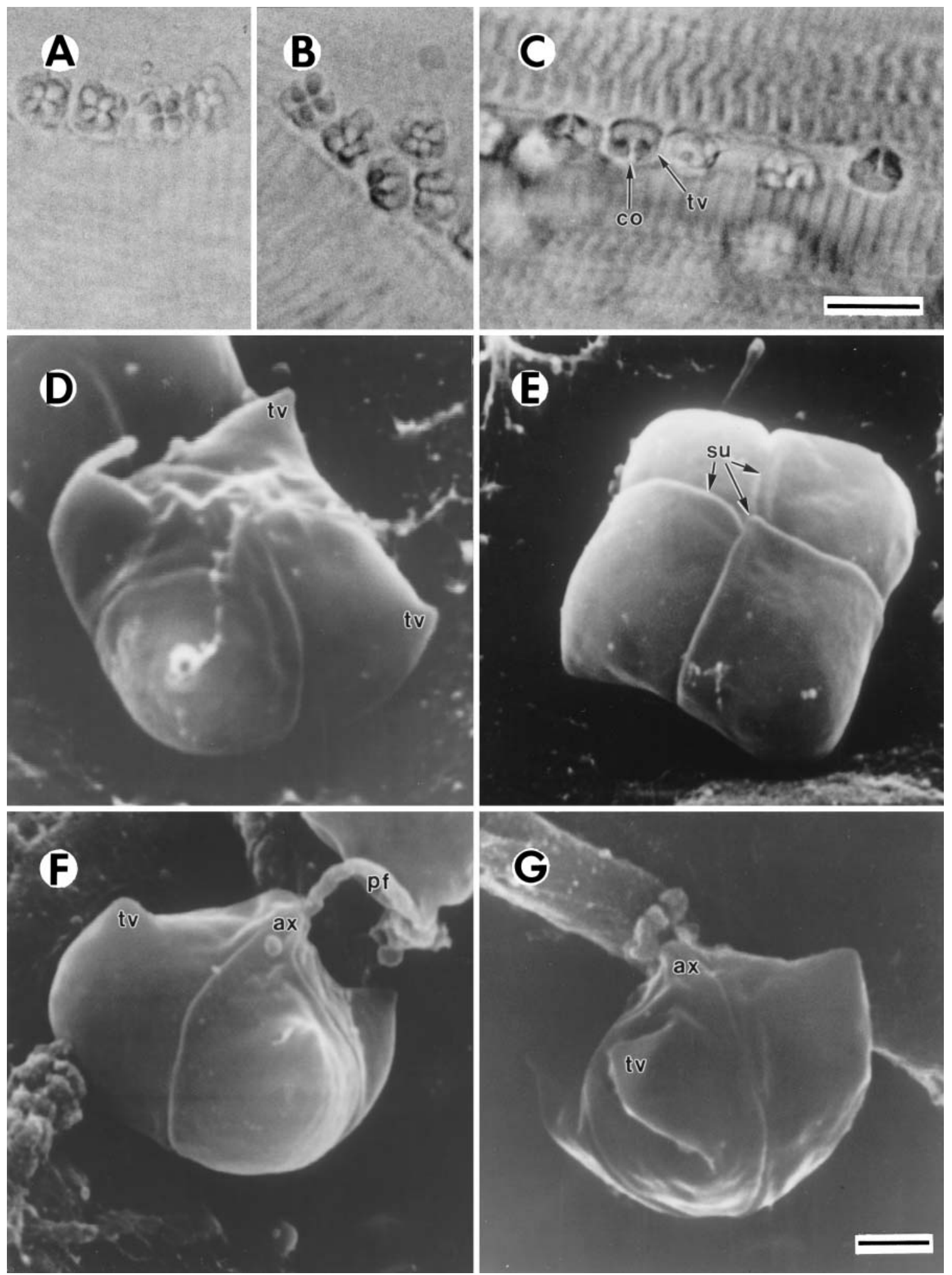

Fig. 2. Brevoortia tyrannus. Spores of Kudoa clupeidae from somatic musculature of juveniles (A-C) wet-mounts: (A,B) apical views; note rounded quadrate shape, with 4 equal-sized polar capsules; (C) lateral view; note cone-shaped projection at apex (co) and slightly uplifted anterio-lateral tips of the spores (tv). (D-G) scanning electron micrographs: (D) apical-lateral view. (E) basal view; note the suture (su) between valves at the base of the spore, only 2 valves met. (F) lateral view with extruded polar filaments (pf). (G) latero-basal view; note the 2 types of extension borne by each valve, the apical papilla-like projection (ax) and the uplifted anterio-lateral tip (tv). Scale bars $(A-C)=10 \mu m_{i}$ scale bars $(D-G)=1 \mu \mathrm{m}$ 

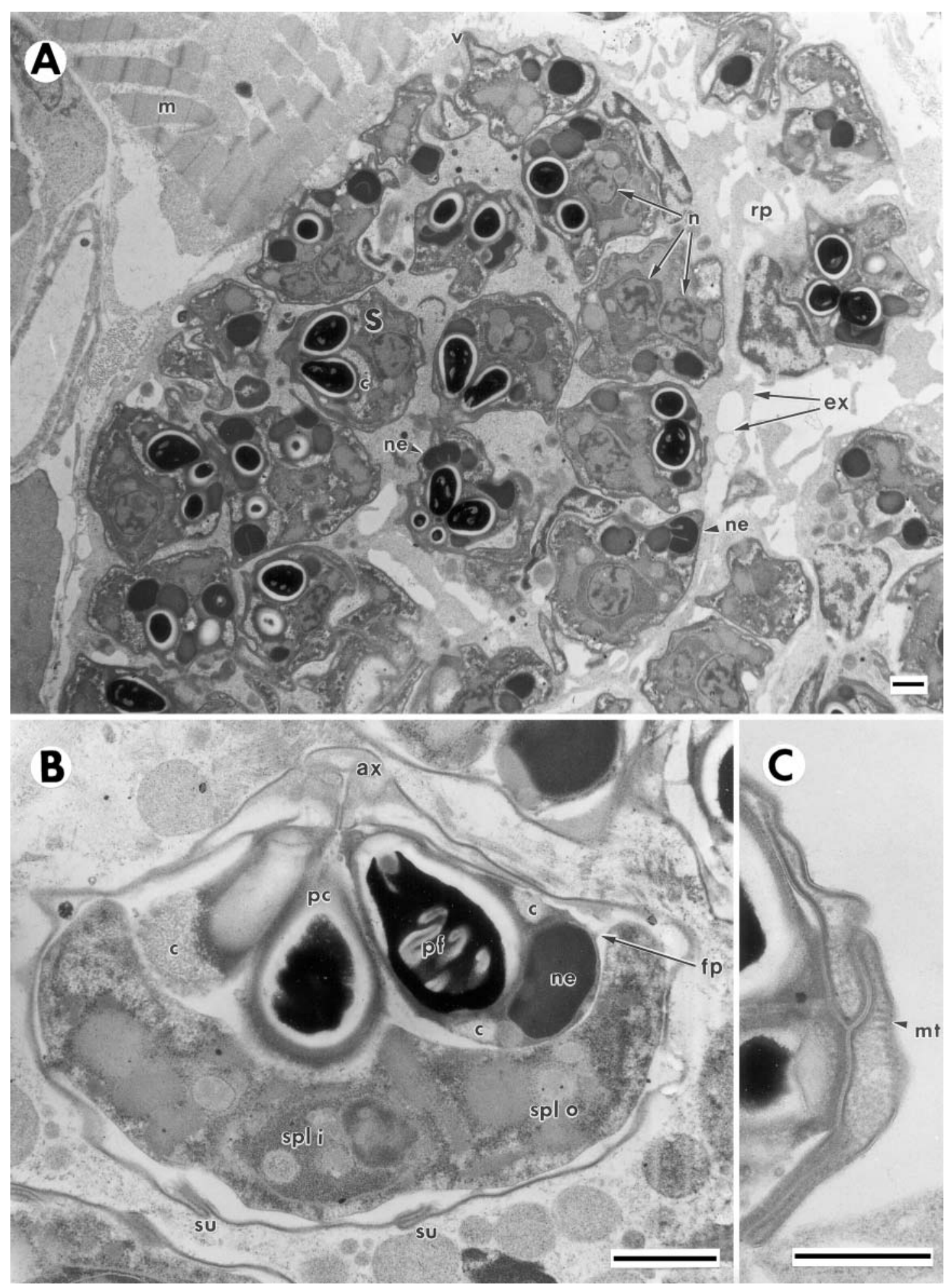

Fig. 3. Brevoortia tyrannus. Transmission electron micrographs of Kudoa clupeidae spores from the somatic musculature of juveniles. (A) Numerous spores (s) lie within a rupturing plasmodium (rp) which has some villosities (v) and pedunculated extensions (ex); note proximity to muscle of host $(\mathrm{m})$; in some spores; note crescent-shaped mottled nucleoplasm of the capsulogenic nucleus (c), adjacent to the dense cleaved chromatin of the capsulogenic nucleus in the shape of a distended letter $\mathrm{E}$ (ne); also note sporoplasm in the basal part of the spores, which contain irregular nuclei (n) that are amoeboid in shape with heterogenous, frequently peripheral chromatin. (B) Longitudinal section though the center of a spore showing the apical extensions (ax) and sutures between valves (su); the capsulogenic cells have polar capsules (pc), with 2 to 3 turns of the polar filament (pf), and bear filamentous projections (fp); the sporoplasm consists of an inner spherical cell with a densely granular cytoplasm (spl i), and an outer crescentric cell with a less dense cytoplasm, with more inclusions ( $\mathrm{spl}$ o). (C) Oblique section through the apex of a spore showing microtubules (mt) in an apical projection. All scale bars $=1 \mu \mathrm{m}$ 

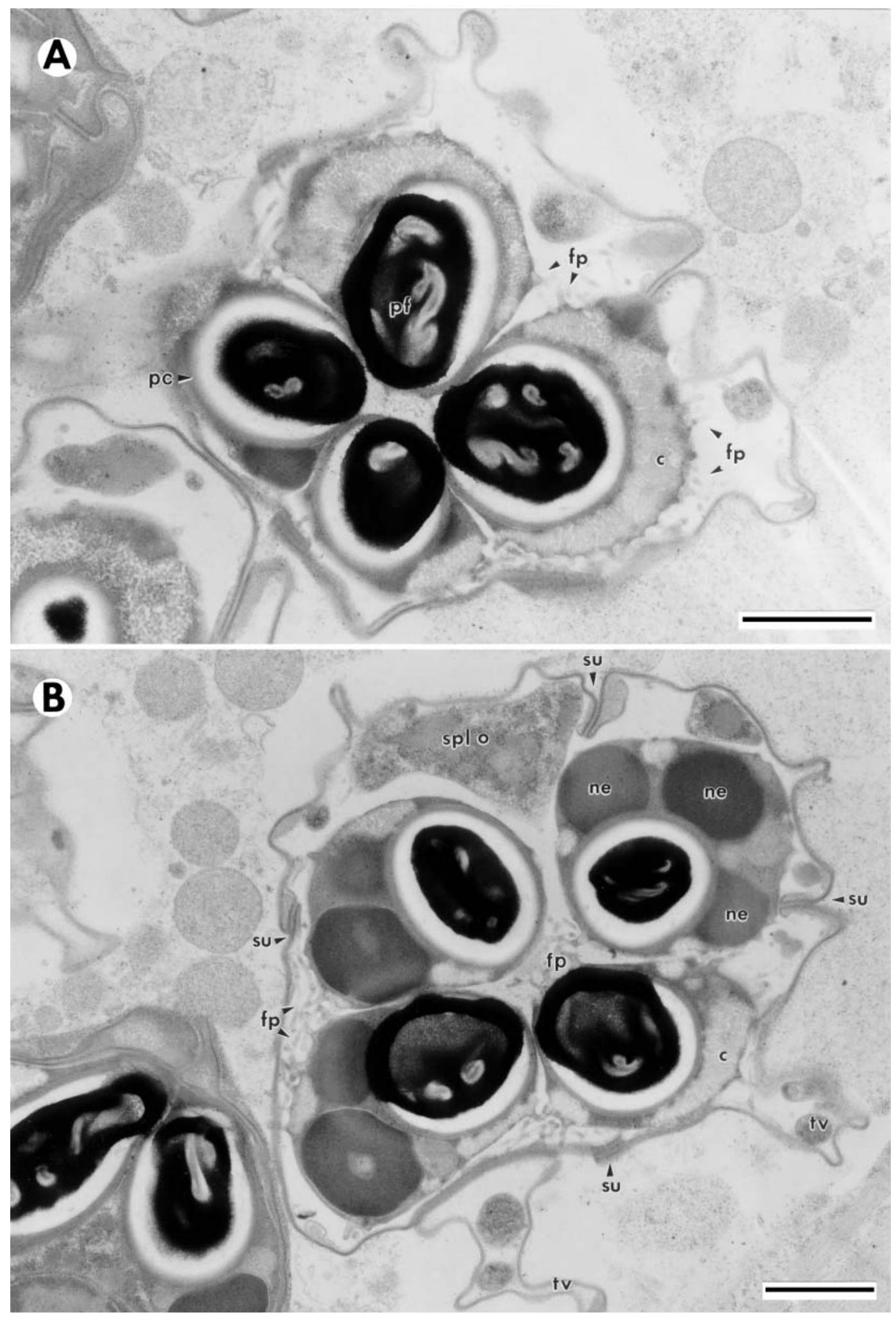

Fig. 4. Brevoortia tyrannus. Transmission electron micrographs of Kudoa clupeidae spores from the somatic musculature of juveniles. (A) Transverse-oblique section near apex of spore. (B) transverse section slightly deeper into the spore. The coiled polar filament (pf) is contained within the polar capsule (pc), which is cupped by a crescent-shaped region of mottled nucleoplasm (c). Depending on the plane of section, up to 3 lobes of condensed cleaved chromatin (ne) lie in the nucleoplasm. The filamentous projections ( $\mathrm{fp}$ ) extend from the surface of the capsulogenic cells. In the deeper section, the 4 sutures (su) between the spore valves can be recognized, and 2 of the uplifted tips to the spore valves (tv) are present. The outer sporoplasmic cell (spl o) is also in the plane of section. Scale bars $=1 \mu \mathrm{m}$ 


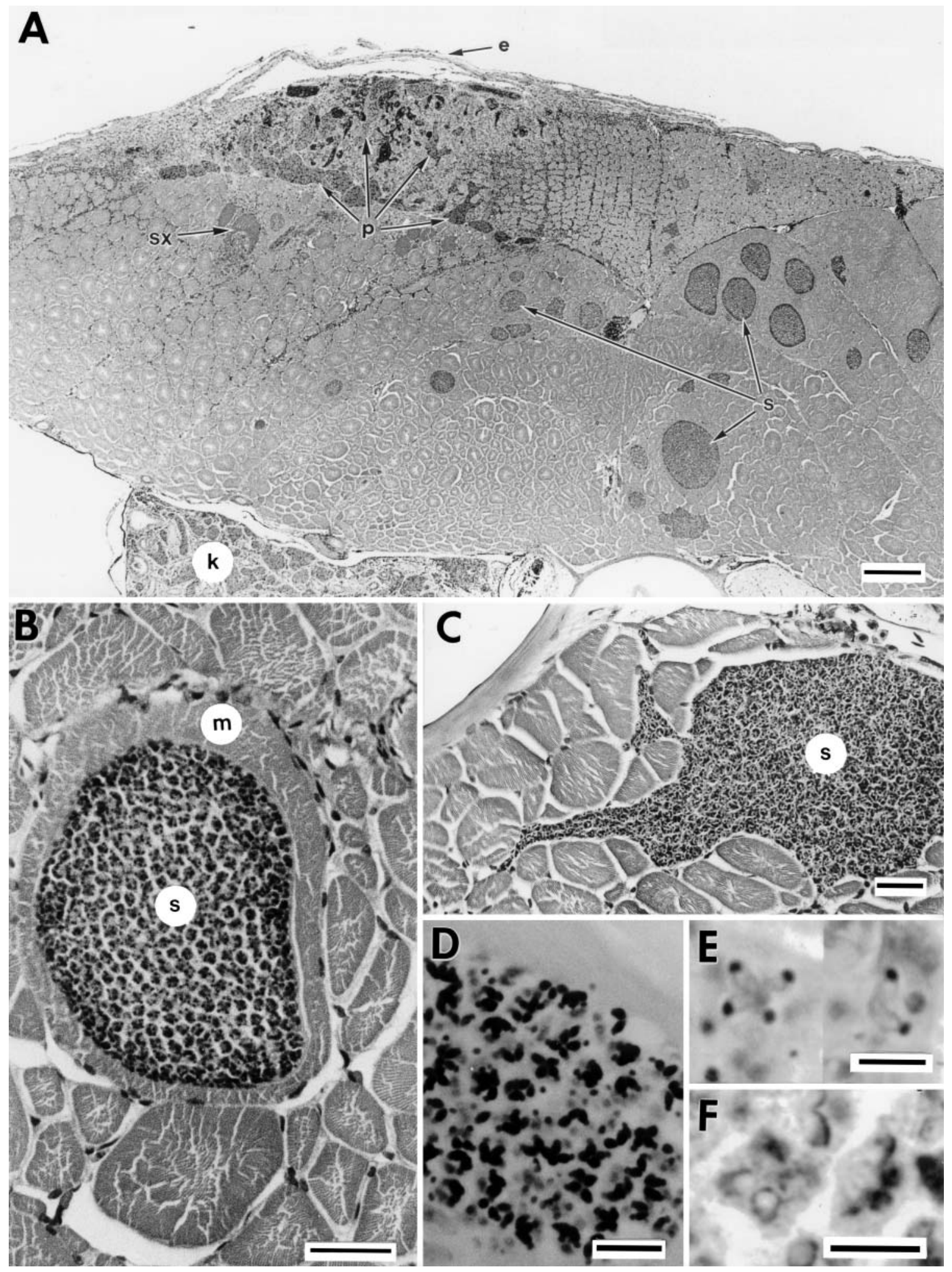

Fig. 5. Brevoortia tyrannus. (A) Overview of hypaxial and epaxial muscles of fish infected with Kudoa clupeidae spores (s) and a lesion with invasive extrasporogonic myxosporean (p); intact epidermis lies over the lesion (e); most of the spores are contained within a myomere, but some spores are noted exiting from a myomere (sx); extrasporogonic myxosporeans are also present in this fish's kidney $(\mathrm{k})$; scale bar $=200 \mu \mathrm{m}$. (B) Mature spores (s) located in a moderately enlarged myomere $(\mathrm{m})$; scale bar $=50 \mu \mathrm{m}$. (C) Mature spores (s) present between myomeres, extending throughout the musculature in several directions; scale bar $=50 \mu \mathrm{m}$. (D) Gram stain demonstrating quadrate structure of spores and polar capsules; scale bar $=10 \mu \mathrm{m}$. (E) PAS stain defines walls of the polar capsules and shows the condensed nuclear material at the base of the capsule; scale bar $=5 \mu \mathrm{m}$. (F) Protargol stain demonstrates the nuclear material extending approximately one-third of the distance up from the base of the polar capsule; scale bar $=5 \mu \mathrm{m}$ 
Table 1. Brevoortia tyrannus. Infections (n) and mean length of Atlantic menhaden sampled from the Pocomoke River in 1999 and 2000 (raw data). Myxo only: myxosporean infection only; Myxo + Kudoa: myxosporean infection and Kudoa clupediae infection; Kudoa only: K. clupediae infection only

\begin{tabular}{|c|c|c|c|c|c|c|}
\hline & $\begin{array}{c}\text { No. } \\
\text { sampled }\end{array}$ & $\begin{array}{l}\text { Gross } \\
\text { lesion }\end{array}$ & $\begin{array}{l}\text { Myxo } \\
\text { only }^{\mathrm{a}}\end{array}$ & $\begin{array}{l}\text { Myxo } \\
+ \text { Kudoa }\end{array}$ & $\begin{array}{c}\text { Kudoa } \\
\text { only }\end{array}$ & $\begin{array}{l}\text { Length } \\
\text { (mm) }\end{array}$ \\
\hline \multicolumn{7}{|l|}{1999} \\
\hline Apr & 21 & 0 & 0 & 0 & 3 & 38.2 \\
\hline May & 39 & 1 & 0 & 4 & 35 & 42.4 \\
\hline Jun & 49 & $33^{\mathrm{b}}$ & 5 & 22 & 16 & 50.9 \\
\hline Jul & 16 & 2 & 0 & 4 & 7 & 69.7 \\
\hline Aug & 8 & 0 & 0 & 2 & 6 & 94.4 \\
\hline Sep & 8 & 0 & 0 & 0 & 8 & 95.9 \\
\hline Oct & 5 & 0 & 0 & 0 & 5 & 104.6 \\
\hline \multicolumn{7}{|l|}{2000} \\
\hline Mar & 4 & 0 & 0 & 0 & 0 & 34.2 \\
\hline Apr & 20 & 0 & 1 & 1 & 0 & 36.6 \\
\hline May & 24 & 7 & 0 & 12 & 11 & 45.6 \\
\hline Jun & 25 & 3 & 0 & 12 & 13 & 62.4 \\
\hline Jul & 23 & $17^{\mathrm{c}}$ & 0 & 0 & 23 & 98.1 \\
\hline Aug & 3 & $3^{c}$ & 0 & 1 & 2 & 109.3 \\
\hline \multicolumn{7}{|c|}{$\begin{array}{l}{ }^{a} \text { Extensive myxosporean plasmodial invasion throughout the muscles } \\
\text { comprising the gross lesions; deeper muscle involvement or visceral infec- } \\
\text { tions present in fish with no gross lesions } \\
\text { b Every lesion examined by histopathology had myxosporean plasmodial } \\
\text { involvement, but histological processing missed the lesions in } 10 \text { fish } \\
\text { cAll lesions were identified as ulcerative mycosis by histopathology }\end{array}$} \\
\hline
\end{tabular}

Feulgen confirmed that the material was DNA (data not shown); the nuclear material was most probably the condensed, trilobed-chromatin noted by TEM (Fig. 3A,B). Protargol stain demonstrated that the crescent-shaped nucleus of the capsulogenic cells was positioned around the base of the polar capsule in a manner similar to the cup of an acorn. The nuclear cup extended approximately one-third of the way up the capsule and stained darkly with protargol stain (Fig. 5F).

Kudoa clupeidae spores infected $74 \%$ of all Pocomoke River juvenile Atlantic menhaden collected for histopathology in 1999, and $75 \%$ of those collected in 2000 (Table 1). In 1999 and 2000, spore prevalence was low in April (14 and 5\%, respectively), increased sharply in May (90 and 96\%, respectively), and then either dropped slightly or remained high through June (78 and 100\%, respectively) and July (69 and 100\%, respectively). In later months (August to October), low numbers of fish precluded determination of spore prevalence.

\section{Plasmodia: histopathology}

The histopathology of the lesions seen by gross examination of fish collected from April to June showed that numerous plasmodia, consistent with extrasporogonic stages of a myxosporean, were abundant in the muscles and dermis (Fig. 6A-D). These plasmodia were highly invasive and caused externally visible raised lesions. Although the epaxial and hypaxial muscles were the principal sites of infection, plasmodia were also found in the cranial, opercular, and branchial musculature (Fig. 6E). Occasionally, plasmodia were observed in visceral organs, including kidney and liver (Fig. 6F).

The extent of the plasmodial invasion into tissue varied during the $6 \mathrm{wk}$ period during which lesions were observed. In most fish caught early during this period, the plasmodia extended through muscle, but the epidermis remained intact. In fish with relatively large lesions, the plasmodia extended from the dermis through both red and white muscles to the vertebrae (Fig. 6A,B). When the overlying epidermis was intact, lesions had little inflammatory response to the plasmodia (Fig. 6A). Some plasmodia extended through the epidermis and formed a raised mass on the surface (Fig. 6B,C). Fish caught several weeks later showed some evidence of wound-healing by fibrosis at the raised lesion margin (Fig. 6C). The plasmodial mass in these cases was separated from the underlying tissue, or had sloughed, leaving an open wound. Pitted ulcers contained some remnant plasmodia, in addition to mild to moderate inflammatory infiltrates of lymphocytes and macrophages (Fig. 6D).

Plasmodia were highly pleomorphic (Fig. 7A), and the secondary and tertiary cells they contained varied in shape, size, and staining characteristics. For example, some plasmodia were strongly basophilic, while others were more eosinophilic. Nuclei within the plasmodia also varied greatly: some were large, round, and basophilic (Fig. 7B,C), while other nuclei were small, almost linear, appearing in pairs (Fig. 7C,D). Some plasmodia had a very dense basophilic center surrounded by a paler eosinophilic substance, with a peripheral ring of dense, small nuclei just beneath the cell membrane (Fig. 7E,F).

Plasmodia were found in each of the gross lesions examined by histopathology during May to July 1999 and April to June 2000 (Fig. 8, Table 1). Kudoa clupeidae spores were present in Atlantic menhaden caught earlier in the year, prior to finding fish with lesions or invasive plasmodia. In 1999, prevalence of K. clupei- 


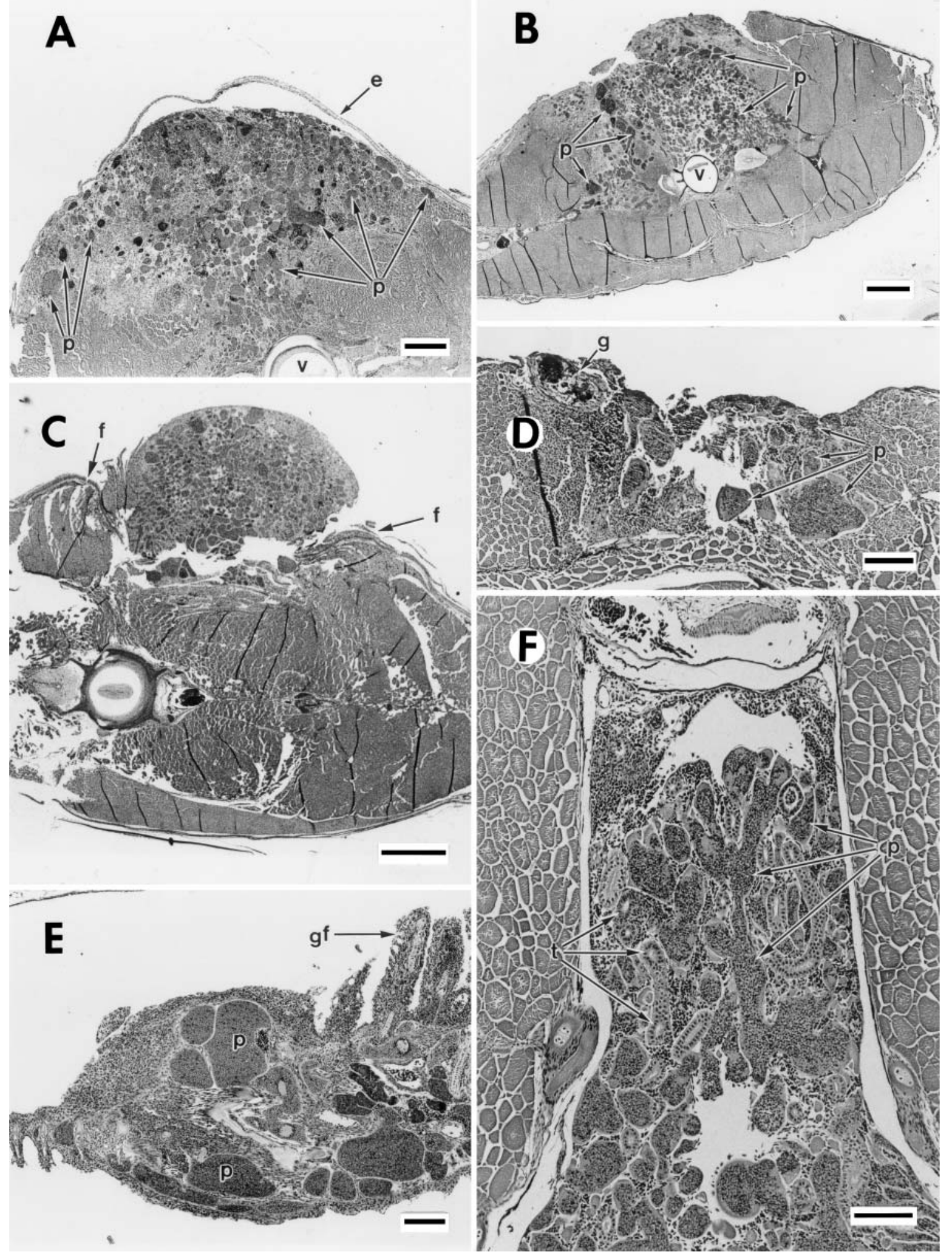

Fig. 6. Brevoortia tyrannus. (A) Lesion containing extrasporogonic plasmodia (p) extending from the vertebrae (v) to just under the epidermis (e). Arrows point to selected plasmodia in the lesion; scale bar $=250 \mu \mathrm{m}$. (B) Plasmodial lesion extending from vertebrae to the surface of the fish; epidermis no longer covers the lesion; scale bar $=500 \mu \mathrm{m}$. (C) Plasmodial lesion forming a raised mass on the surface of the fish; healing by fibrosis (f) is evident at the margins of the lesion, which lacks an epidermis; scale bar $=$ $500 \mu \mathrm{m}$. (D) Plasmodial lesion which forms a pitting ulcer; granuloma (g) is located at the left margin of the lesion, accompanied by a small fibroblastic infiltrate; plasmodia (p) are present in the deeper regions of the ulcer; scale bar $=200 \mu \mathrm{m}$. (E) Plasmodia (p) distending the branchial arch; gill filament (gf) can be seen; scale bar $=100 \mu \mathrm{m}$. (F) Plasmodia (p) located throughout the kidney; plasmodia have replaced most of the renal tubules $(\mathrm{t})$; scale bar $=100 \mu \mathrm{m}$ 


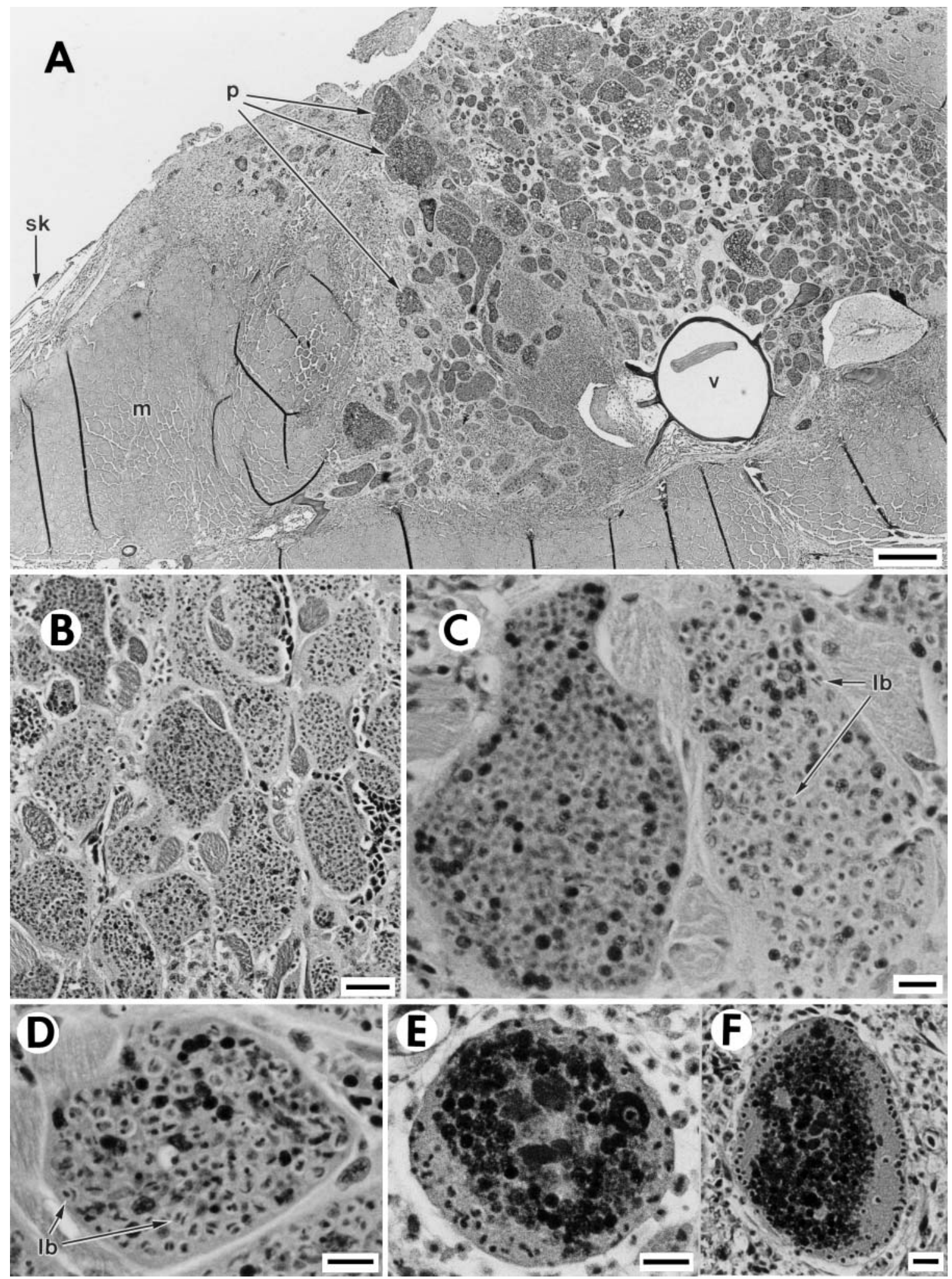

Fig. 7. Brevoortia tyrannus. (A) Extrasporogonic plasmodia (p) extending from the vertebrae (v) to the ulcerated surface of the fish; plasmodia (p) vary greatly in their size, shape and internal morphology, extending through skin (sk) and muscle (m); arrows point to selected plasmodia (p) in the lesion; scale bar $=200 \mu \mathrm{m}$. (B) Plasmodia located within and between myomeres; scale bar $=$ $50 \mu \mathrm{m}$. (C) Two plasmodia with quite different internal morphology; protoplasm of the left plasmodium is quite eosinophilic with large rounded basophilic nuclei; adjacent plasmodium contains paler protoplasm with pleomorphic, oblong, linear bodies (lb), each surrounded by an apparent halo; scale bar $=10 \mu \mathrm{m}$. (D) Plasmodium with parallel basophilic linear bodies surrounded by a halo; scale bar $=10 \mu \mathrm{m}$. (E), (F) Plasmodia with peripheral ring of discrete basophilic structures and central basophilic protoplasm; 


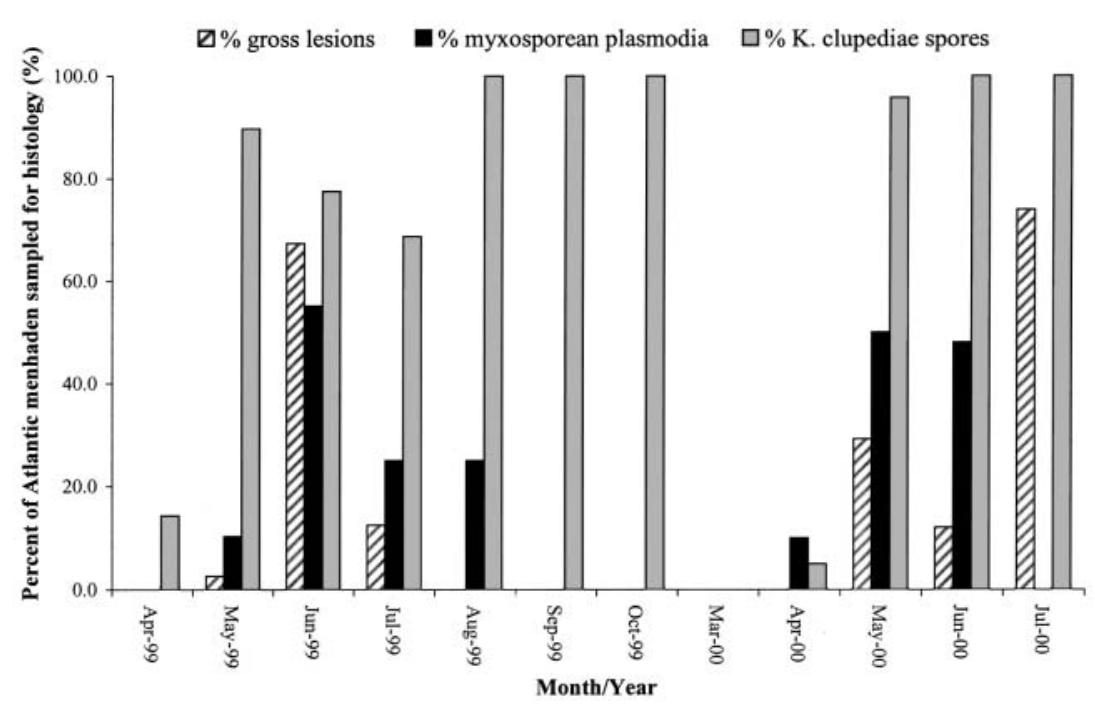

Fig. 8. Brevoortia tyrannus. Percent of Atlantic menhaden from Pocomoke River with gross lesions, myxosporean plasmodia infections, and Kudoa clupeidae spores, and in each monthly histology sample

dae spores was 14, 90, 78 and $69 \%$ in April, May, June, and July, respectively, while prevalence of invasive plasmodia was $0,10,55$ and $25 \%$ during the same period. A similar pattern was observed in 2000.

\section{Plasmodia: ultrastructure}

The large plasmodia of variable morphology were recognized as vegetative stages of a myxosporean (the trophozoite stage). The surfaces of the plasmodia were elaborate and adorned with irregular branching, pedunculated and fused extensions, extending for up to $4.5 \mu \mathrm{m}$ (Fig. 9A). In immature plasmodia, the cytoplasm was homogenous (not divided into distinct ectoplasm and endoplasm), and finely granular. The plasmodia (primary cell) contained numerous vegetative nuclei, numerous secondary generative cells, small vacuoles, and electron-dense flocculent material (Fig. 9). Vegetative nuclei were amoeboid, reaching up to $6.25 \mu \mathrm{m}$ in maximal dimension, with marginated and clumped chromatin, and 1 or 2 small homogenous nucleoli. Some larger vegetative nuclei, presumably those that were more mature, were dominated by chromatin (Fig. 9B). The secondary generative cells had homogenous cytoplasm containing numerous mitochondria, and typically 1 or 2 cross-sections of nuclei (Fig. 9B); in the latter case, 1 nucleus had marginated and clumped chromatin, and the other nucleus was dominated by chromatin. Nucleoli were occasionally seen in the secondary generative cells.

More mature plasmodia containing a greater diversity and complexity of cells had a surface that varied within and between individuals and included regions of broad pseudopodia-like structures, elaborate extensions as described above, and villosities (Fig. 10A-C). Many maturing plasmodia were divided into distinct ectoplasm and endoplasm (Fig. 10A). The ectoplasm was homogenous and finely granular, and sometimes channels from the surface of the plasmalemma extended deep into the ectoplasm (Fig. 10D). These were interpreted as deep infoldings of the plasmalemma, rather than pinocytotic channels, because no pinocytotic vesicles were evident. Around some plasmodia, fibrous material was seen (Fig. 10C,D), which in some cases formed a thick layer (Fig. 10E). The endoplasm of maturing plasmodia was highly vacuolated and contained numerous spherical vegetative nuclei and secondary generative cells, and occasional cell doublets comprising a secondary cell containing a tertiary cell (Fig. 11A-D). Secondary generative cells were amoeboid, with numerous mitochondria, and had a large amoeboid nucleus with clumped chromatin and a large nucleolus (Fig. 11A,B). In some sections, we observed 2 cells, 1 with dark cytoplasm and 1 with lighter cytoplasm, closely associated and wrapped around each other: this was identified as the formation of a cell doublet (Fig. 11C). In fully formed cell doublets, the inner tertiary cell had a dark cytoplasm and elongate nucleus, and the outer secondary cell had a light cytoplasm and approximately spherical nucleus (Fig. 11D).

Early sporogonic stages were observed in 1 fish, and in this case the plasmodium was not in the somatic musculature but in the kidney (Fig. 11E,F). In this plasmodium, the cytoplasm contained the 2 types of vegetative nuclei also seen in the early plasmodia, but also contained numerous developing stages believed to be undergoing early sporogony, characterized by multiple cells and sections of nuclei. No spore primordia, such as polar capsules with attached external tubes, were seen.

\section{Other parasites}

In addition to the Kudoa clupeidae spores and invasive plasmodia, we noted other parasitic infections and abnormalities. Gross examination revealed that the isopod Olencira praegustator (Latrobe, 1802) was commonly attached to the gill arches in the buccal cavity. Histopathological findings included: unidentified multicellular plasmodia adhering to the epithelium of the 

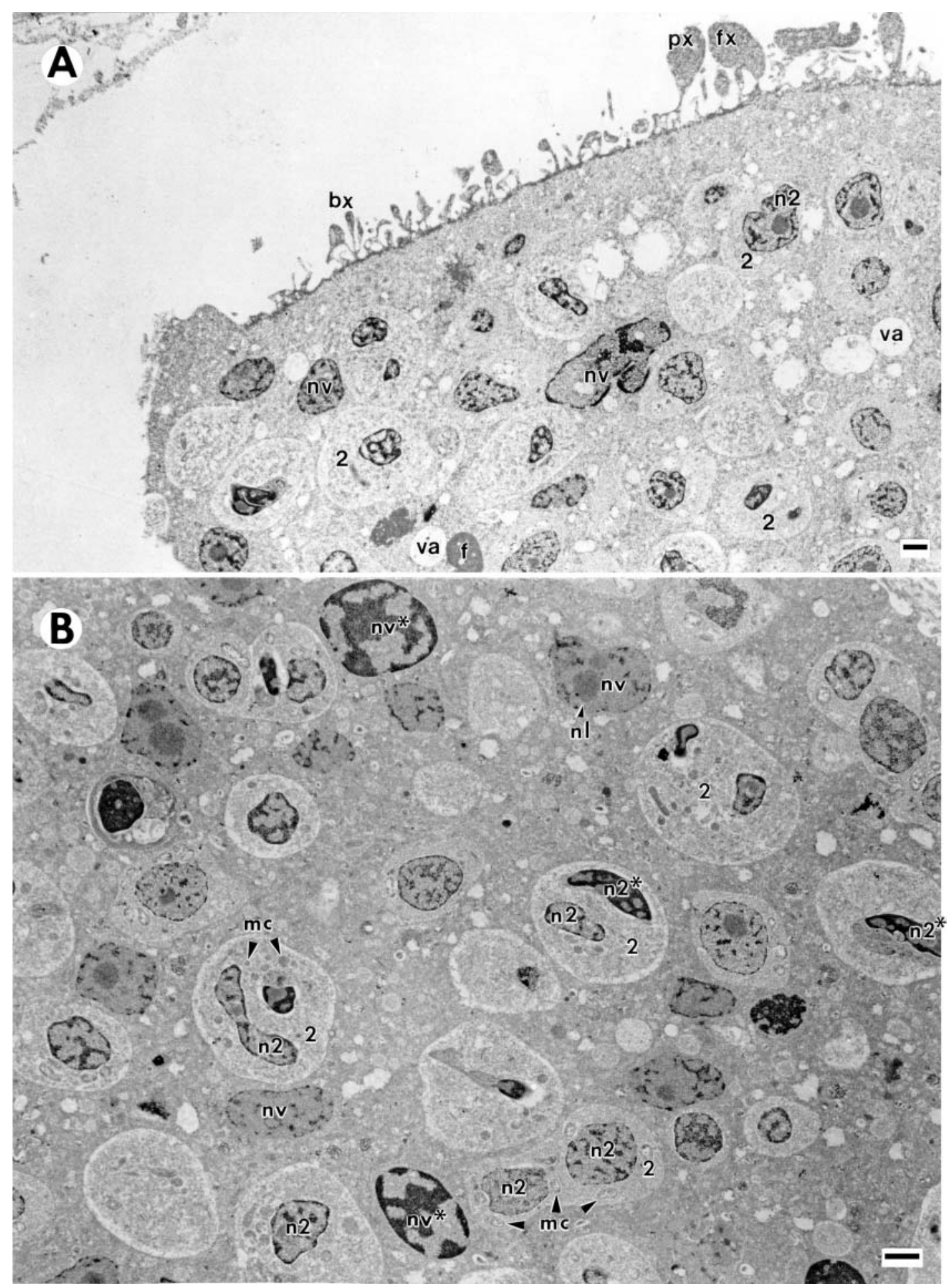

Fig. 9. Brevoortia tyrannus. Transmission electron micrographs of large, immature plasmodia containing vegetative nuclei and secondary generative cells from somatic musculature of juveniles. (A) Early plasmodium; (B) detail of inner region of more mature plasmodium. The elaborate surface of the plasmodium is adorned with irregular branching extensions (bx), and fused and pedunculated extensions ( $\mathrm{fx}, \mathrm{px}$ ). The homogenous cytoplasm contains numerous vegetative nuclei, secondary generative cells (2), small vacuoles (va), and sparse flocculent material (f). Vegetative nuclei in the cytoplasm, and those in secondary generative cells are of 2 types: vegetative nuclei may have peripheral and clumped chromatin (nv) and a nucleolus (nl), or be dominated by chromatin $\left(\mathrm{nv}^{*}\right)$; nuclei in the generative cells may also have peripheral and clumped chromatin (n2) or be dominated by chromatin $(\mathrm{n} 2 *)$. The numerous mitochondria $(\mathrm{mc})$ in the secondary cells are easily seen. Scale bars $=1 \mu \mathrm{m}$ 

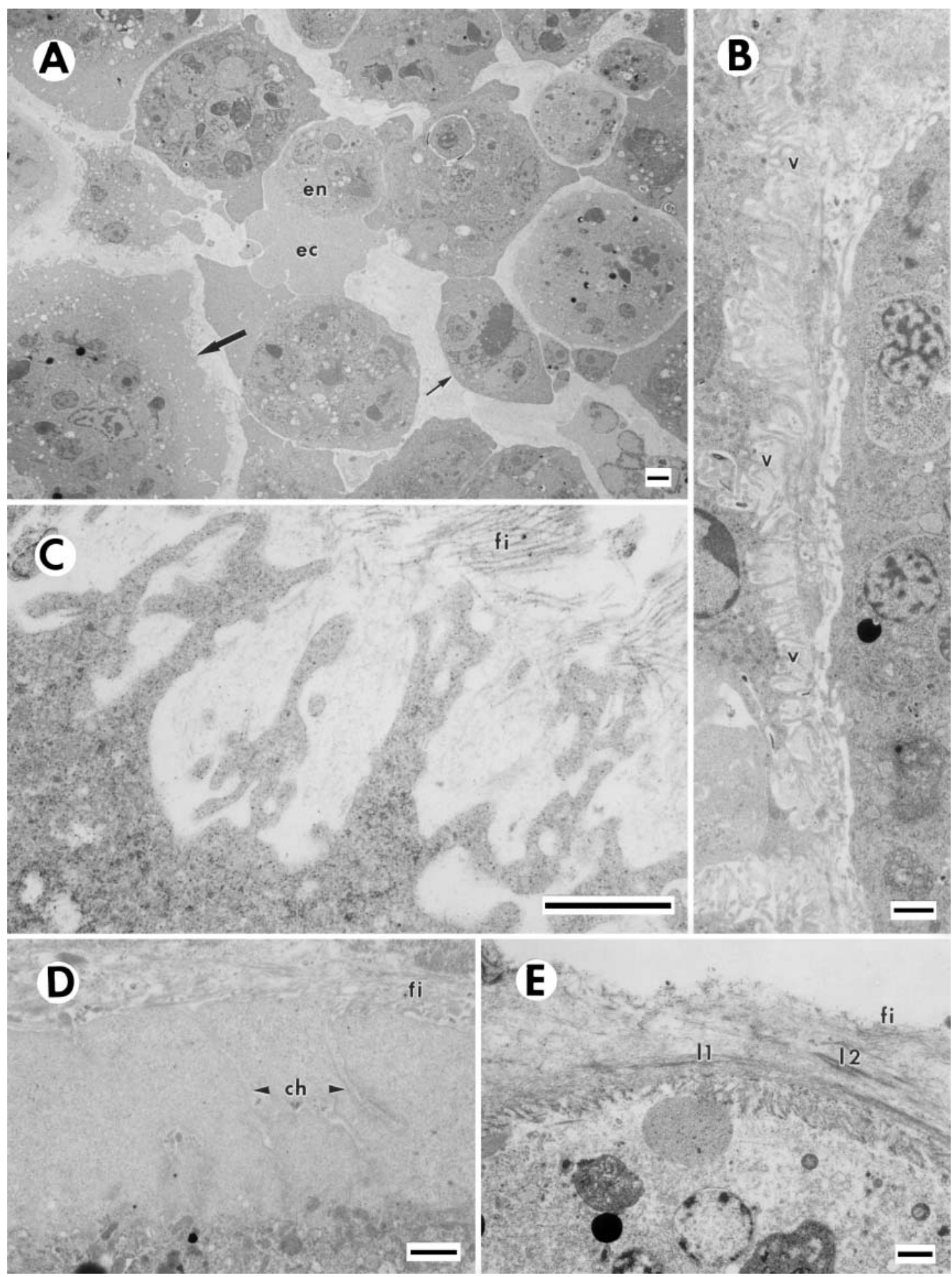

Fig. 10. Brevoortia tyrannus. Transmission electron micrographs of large, maturing plasmodia from the somatic musculature of juveniles. (A) Numerous maturing plasmodia, showing variations in their surface from smooth (small arrow) to elaborately adorned (large arrow), and variations in interior ultrastructure, with many plasmodia having a distinct pale ectoplasm (ec) and a more dense endoplasm (en) containing enlarging secondary and tertiary cells. (B) Detail of surface of 2 adjacent plasmodia; surface of the plasmodium on the left comprises numerous villosities (v), giving a fringe-like appearance; beneath the surface some regions of the ectoplasm contain numerous organelles, possibly mitochondria, while in other regions the cytoplasm is homogenous and appears to lack organelles; surface of the plasmodium on the right is smoother with fewer villus-like extensions, and in the underlying ectoplasm, organelles, possibly mitochondria, are more evenly distributed. (C) Detail of the surface of a plasmodium showing elaborate branching extensions, beyond which lie numerous fibers (fi), possible fibrin; note also the fine material occupying the spaces between the branching extensions. (D) Surface of a plasmodium with a distinct homogenous ectoplasm, through which run channels (ch) reaching toward the dense endoplasm; beyond the plasmodia lie layers of loosely packed fibrous material (fi). (E) Surface of a plasmodium, showing a fringe-like region, beyond which lie 2 layers of fibrous material (11, 12), which become less densely packed distally; organization of the fibrous material (fi) into layers following the shape of the plasmodium can clearly be seen. Scale bars $=1 \mu \mathrm{m}$ 

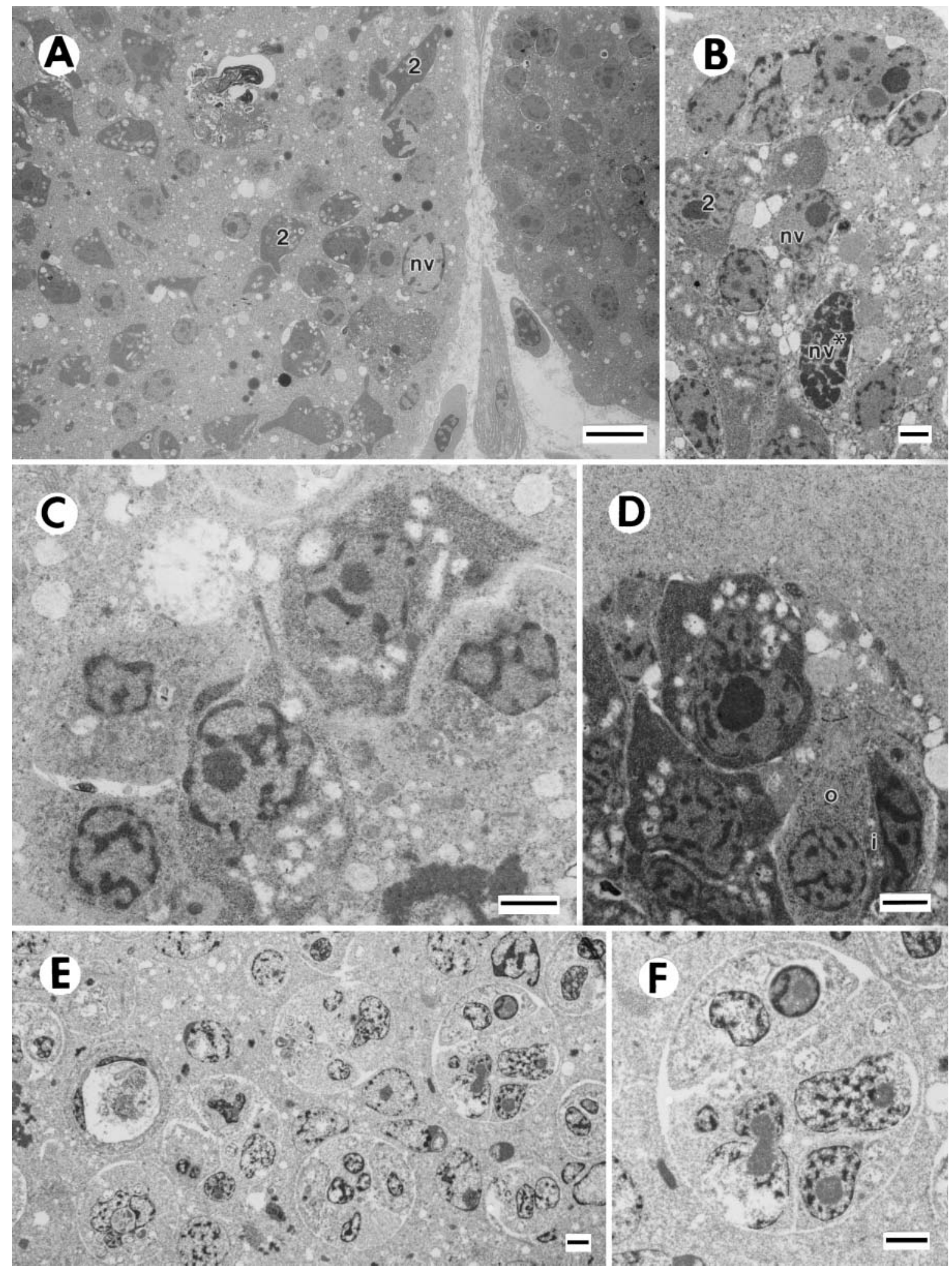

Fig. 11. Brevoortia tyrannus. Transmission electron micrographs of large, maturing plasmodia from somatic muscle (A-D) and kidney $(E-F)$ of juveniles. (A, B) Plasmodia with highly vacuolated endoplasm, containing numerous vegetative nuclei with peripheral and clumped chromatin (nv), or dominated by chromatin $\left(\mathrm{nv}^{*}\right)$ and secondary generative cells (2) which are amoeboid, with numerous mitochondria, and a large amoeboid nucleus with clumped chromatin and a large nucleolus. (C) Possible formation of a cell doublet, with 2 cells, 1 with pale homogenous cytoplasm, and 1 with darker cytoplasm, wrapped closely together. (D) Cell doublet: outer cell (o) has pale homogenous cytoplasm; inner cell (i) has darker cytoplasm. (E) More developed plasmodia; within the spherical structures there are profiles of multiple cells and nuclei, perhaps indicating an early stage of sporogony. (F) Higher magnification of part of the plasmodia shown in (E). Scale bar in $(A)=5 \mu \mathrm{m}$; scale bars in $(B-F)=1 \mu \mathrm{m}$ 
lower gastrointestinal tract; cysts of multicellular parasites indicative of developing myxosporean spores in some renal corpuscles of the trunk kidney; mature Myxobolus spp. spores in the bone of the gills, buccal cavity and fins; and epitheliocystis inclusions in gill filaments. These conditions persisted throughout the sampling season with no clear pattern or prevalence.

In the intestine, the unidentified multicellular plasmodia typically appeared as subspherical to oblong basophilic bodies that measured approximately $7.5 \mu \mathrm{m}$ wide and varied from 10 to $37.5 \mu \mathrm{m}$ in length. These plasmodia were attached to the luminal surface of the lower intestinal columnar epithelium near the anal pore. In well-preserved specimens, it was apparent the plasmodia were attached to the epithelium by pseudopodialike structures extending from relatively little cytoplasm containing mostly multiple basophilic nuclei.

In the renal corpuscles of the trunk kidney, the cyst of developing myxosporean spores occupied the vascular epithelium of the glomeruli, usually encompassing half or all of the glomerular rete. The developing spores were spherical to subspherical, approximately 4 to $5 \mu \mathrm{m}$ in diameter, surrounded by a halo of unstained space. Some spores had a pair of ovoid basophilic bodies terminally located close together, and a single basophilic nucleus located below the ovoid bodies. These spores were tentatively identified as Sphaerospora sp.

In the bone of the gill, buccal cavity and fins, the bilaterally symmetrical spores were ovoid in valvular view and biconvex in sutural view, with 2 equal-sized polar capsules at the apex of the spore. This morphology is consistent with the myxosporean genus Myxobolus. The Myxobolus spores measured approximately $8.0 \mu \mathrm{m}$ long, $7.0 \mu \mathrm{m}$ wide, and $5.0 \mu \mathrm{m}$ thick. A pair of prominent polar capsules, approximately $4.0 \mu \mathrm{m}$ long and $3.0 \mu \mathrm{m}$ wide, were terminally located close together. The spores usually had a relatively large clear circular space reminiscent of a vacuole located below the polar capsules.

\section{Deposition of type material}

Histological sections stained with H\&E, PAS and Protargol, and tissues bearing spores and plasmodia have been deposited in the US National Parasite Collection, USDA, ARS, BARC East, Building 1180, Beltsville, Maryland 20705-2350, USA (Email: ehoberg@anri.barc.usda.gov). Their accession numbers are USNPC\#092557.00, USNPC\#092558.00, USNPC\#092559.00, USNPC\#092560.00. Additional histological sections and scanning and transmission electron microscopy samples are in the collection of the corresponding author.

\section{DISCUSSION}

Our most remarkable finding was the presence of numerous extrasporogonic plasmodia of a myxosporean in the muscles and viscera, and abundant mature spores of Kudoa clupeidae (Myxozoa: Myxosporea) in muscles of the head and body of Brevoartia tyrannus. This is the first confirmed report of $K$. clupeidae spores from young-of-the-year Atlantic menhaden in Chesapeake Bay. The spores caused little to no host response or tissue pathology, while the extrasporogonic plasmodia were highly invasive and caused externally visible raised lesions and skin ulceration. There was minimal host response to these plasmodia unless ulceration had occurred.

Our ultrastructural studies indicate that the plasmodia, which are important in the etiology of the skin lesions described here, are clearly myxozoans, and may tentatively be identified as Kudoa clupeidae. The histology demonstrates that the plasmodial myxozoan is responsible for the ulcerative skin lesions we found in young Atlantic menhaden from the Chesapeake watershed during spring and early summer. Identification of this previously unrecognized cause of skin lesions has significant implications since a number of investigators have proposed that gross occurrence of ulcerative lesions be used as a biomarker for toxic algal blooms (Noga et al. 1996, Burkholder \& Glasgow 1997, CDC 1997). Our findings show a clear parasitic etiology for the skin lesions in these juvenile fish and demonstrate that assumption of gross lesions as indicative of only algal, dinoflagellate or fungal etiology is inappropriate. Histopathological examination of skin lesions is essential to identify, with certainty, the presence or absence of specific pathogens.

\section{Pathology of the extrasporogonic plasmodia}

The skin lesions we report here occurred in youngof-the-year Atlantic menhaden (averaging 34 to $52 \mathrm{~mm}$ fork length) in the Pocomoke River during a period of 4 to $6 \mathrm{wk}$ in early spring of 1999 and 2000 . Lesions reported in larger Atlantic menhaden from North Carolina to Maryland most frequently occur in the late summer and early fall (Ahrenholz et al. 1987, Dykstra et al. 1989, Kane et al. 1998, Blazer et al. 1999), and these lesions, many located near the vent and caudal peduncle, have been shown to be predominantly chronic ulcerated mycotic Aphanomyces sp. infections (Dykstra et al. 1986, Noga \& Dykstra 1986, Levine et al. 1990b, Blazer et al. 1999). In our young fish, the gross skin lesions consisted of raised or ulcerated pink foci between 3 and $5 \mathrm{~mm}$ located on all surfaces of the body. Sections of grossly 
observed lesions examined by light microscopy contained extrasporogonic myxosporean plasmodia located within and between muscle bundles, while others extended through the surrounding connective tissue, and in some cases, with extension to dermis and epithelium. Minimal inflammatory response was noted unless the organism had ulcerated the epidermis. This is in contrast to the extensive chronic inflammation found in the cases of ulcerative mycosis seen in the late summer and fall (Kane et al. 1998, Blazer et al. 1999).

Some of the ulcerated lesions caused by the rupture of the plasmodia through the epidermis showed signs of healing. The plasmodia appeared to slough off, creating a crater-like ulcer. Granulation tissue and fibrosis were present at the margins of such ulcers, indicating the onset of wound-healing. In the case of large ulcers, where healing is slow, the ulcers could serve as a portal of entry for opportunistic pathogens such as fungi, particularly the Aphanomyces spp., which is found in Atlantic menhaden later in the summer. In other words, whereas the fungus may be a primary cause of skin ulcers, the myxozoan described here may also cause ulcerative lesions and predispose fish to secondary infections by Aphanomyces spp.

Significant pathology caused by a developmental stage of a myxosporean in wild fish, such as we now report, is infrequently reported. Most of the recently described diseases caused by developmental stages of myxosporeans, such as swim bladder inflammation, proliferative kidney disease, and parasitic encephalitis, are reported in fishes held in captivity for aquaculture purposes (Lom \& Dyková 1995, Frasca et al. 1998). The disparity in reports between wild and farmed species could be due to the frequency of observations. Wild animals with heavy parasitism often succumb to predators. Pathology associated with developmental stages of a myxozoan-like parasite has, however, been reported in a wild higher vertebrate, the mole Talpa europaea (Friedrich et al. 2000).

The pathology we report for the plasmodia is akin to 'boil disease' of barbels, in which Myxobolus pfeifferi infections in somatic muscle produce boils which burst, discharging spores (Schäperlaus 1991). Among myxosporeans principally inhabiting skin and subcutaneous tissue (primarily Henneguya spp. and Myxobolus spp.), none are reported to cause ulcerative lesions (Lom \& Dyková 1995).

\section{Identification of the plasmodium}

Ultrastructural studies demonstrated that the plasmodia were consistent with the extrasporogonic stage of a myxozoan; and the characteristic 'cell-in-cell' arrangement was clearly seen (Figs. 9, 10 \& 11). The large size of the plasmodia, and the numerous vegetative nuclei and generative cells contained within, are characteristic of polysporic plasmodia, commonly seen in histozoic myxosporean species (Lom \& Dyková 1995). An elaborate plasmodial surface, such as the numerous extensions and villosities we observed on some areas of the unencapsulated plasmodium, is known from relatively few species of myxosporeans (Stehr \& Whitaker 1986). Among them are both histozoic species (Myxidium zealandicum, Kudoa paniformis, and $K$. thyrsites) and coelozoic species (M. lieberkuehni, Sphaeromyxa spp., and Zschokkella russelli) (Stehr \& Whitaker 1986).

Most of the plasmodia observed contained neither developing nor mature spores, and thus their identity to genus and species could not be confirmed. However, the presence of an irregular, elaborate, branching, and pedunculated surface on diverse plasmodia (the intact common ones containing the developmental stages [Figs. 9A \& 10A-C], the intact ones containing the rare early sporogonic stages, and a fragmenting plasmodium surrounding Kudoa clupeidae, spores [Fig. 3A]) suggests that the plasmodia may all belong to the same species, K. clupeidae. Furthermore, the most prevalent myxosporean in the young-of-the-year Atlantic menhaden was $K$. clupeidae which, like the plasmodia, occurred in the muscles.

Similar large plasmodia without spores have not previously been reported for Kudoa spp., but only 4 out of 46 species have had plasmodial ultrastructure reported. In a careful examination of the sequential development of $K$. thyrsites, Moran et al. (1999b) found that the only stages they could detect that did not contain spores were very small plasmodia within muscle fibers. Furthermore, the ultrastructure of the plasmodia from Atlantic menhaden is distinct from that of the 4 species of Kudoa that have been described. The irregular pedunculated, fused, and branching extensions on the surface of the unknown plasmodia distinguish it from $K$. paniformis and $K$. thyrsites, both of which have regular microvillus borders, with microvilli measuring $0.1 \times 0.7 \mu \mathrm{m}$ and $0.5 \times 0.9 \mu \mathrm{m}$, respectively (Stehr \& Whitaker 1986). The surface of the unknown plasmodia is also distinct from that of $K$. lunata, which lacks peduculated and fused extensions (Lom et al. 1983). The smoother outer surface, with deep invaginations seen in some partially encapsulated plasmodia in Atlantic menhaden (Fig. 10D), is similar to that seen in $K$. lunata and $K$. quadratum, which have irregular pinocytotic channels (Uspenskaya 1981, Lom et al. 1983). The loss of a microvillar surface in encapsulated plasmodia has been previously reported for $K$. paniformis 
and K. thyrsites (Stehr \& Whitaker 1986). The cytoplasmic organelles further distinguished the plasmodia in the Atlantic menhaden from those of some previously described species of Kudoa. Unencapsulated plasmodia of $K$. paniformis contain multivesicular bodies, and those of $K$. thyrsites contain vesicles, microfilaments, and microtubules (Stehr \& Whitaker 1986), features not seen in the plasmodia in Atlantic menhaden. A further aspect confusing the identification of the plasmodia as $K$. clupeidae is the occurrence of spores of $K$. clupeidae in the population of Atlantic menhaden before these unusual plasmodia were observed.

The kidney myxozoans were suggestive of Sphaerospora sp., but this identification could not be confirmed as mature spores were not observed. Extrasporogonic development has been reported in many Sphaerospora species (Lom \& Dyková 1992), and therefore the possibility that these plasmodia causing the muscle lesions belong to a Sphaerospora sp. should also be considered.

Molecular characterization would be useful to determine the identity of these plasmodia. At present, $18 \mathrm{~S}$ rDNA sequences from about 60 myxozoan species, representing most of the major groups in the phylum, are available (Kent et al. 2001). Although most $18 \mathrm{~S}$ rDNA sequences for myxozoans have been derived from spores obtained from the fish host, a recent study by Frasca et al. (1999) used material from the extrasporogonic stage. These authors reported the identity of an intracellular extrasporogonic multicellular developmental stage of a myxosporean using segments of the small subunit ribosomal RNA (SSU rRNA) gene using PCR, Southern blot hybridization, dideoxynucleotide chain-termination DNA sequencing, and in situ hybridization. Pote et al. (2000) linked the extrasporogonic form responsible for proliferative gill disease in catfish to a new Henneguya species using rDNA comparisons. Therefore, obtaining rDNA sequence of the plasmodia in the present study would be very useful for resolving its identity.

\section{Pathology of Kudoa clupeidae spores}

The co-authors of the current study, as well as other investigators studying Atlantic menhaden in the Chesapeake Bay (W. Vogelbein pers. comm.), commonly observe mature spores (referred to as a pseudocyst: see discussion in Moran et al. 1999c) of an unidentified Kudoa sp. within muscles of Atlantic menhaden, both in normal-appearing fish and in fish with skin lesions. This Kudoa parasite is now identified as $K$. clupeidae. Spores were not specifically associated with the lesions, although the lesions can extend through much of the muscle, some of which may be infected with the spores. This is consistent with the observation by Meglitsch (1947) that K. clupeidae infection of 1 to 2 yr old menhaden $(\mathrm{n}=18$ ) was not associated with skin lesions, despite the presence of cysts, rare trophozoites, and spores in the somatic musculature (Meglitsch 1947). To our knowledge, the only Kudoa species reported from Atlantic menhaden is $K$. clupeidae (Meglitsch 1947), originally described as Chloromyxum clupeidae (Hahn 1917).

There have been reports, however, of ulcers caused by spores of Kudoa clupeidae in the Atlantic herring Clupea harengus, the alewife Alosa pseudoharengus, and the blueback herring Alosa aestivalis (Hahn 1917 , Sindermann \& Rosenfield 1954). Of particular interest is an early observation that 'ulcers [in herring] are external manifestations of advanced infection by a myxosporidian protozoan, Chloromyxum (Kudoa) clupeidae' (Sindermann \& Rosenfield 1954). A similar observation of the internal origin of the lesions was also made by Hahn (1917). Furthermore, both Hahn (1917) and Sindermann \& Rosenfield (1954) also noted that swelling preceded the ulceration. External lesions were only observed in herring older than 1 yr. In herring less than 1 yr old, Sindermann \& Rosenfield (1954) did not report external lesions, despite heavy infection with $K$. clupeidae.

The Atlantic menhaden examined in this study had spores primarily located within myomeres, with no inflammatory response even if many myomeres were infected. Occasionally, spores were located in the fascia, presumably due to rupture following extreme enlargement of the myomere. It is not known how the spore infection affects the host. It is possible that infections that include many myomeres could compromise the ability to swim or escape predators. This was speculated by Linton (1901), who noticed that younger fish (herring) were heavily parasitized while the adults were not infected. Alternatively, Sindermann (1990) postulated that spores may leave the young fish through exit pores 'and evidence of disease is absent' once the fish mature.

Infections of Kudoa spores have been reported to cause localized pathological changes but rarely to affect the physiology, behavior, or life span of the fish host (Egusa 1986). Several species of Kudoa are of commercial importance, because they produce either unsightly cysts in the musculature (K. amamiensis in buri Seriola quinqueradiata and $K$. thyrsites in Atlantic salmon Salmo salar), or are associated with post-mortem myoliquefaction ( $K$. musculoliquefaciens in swordfish Xiphias gladius, K. paniformis in Pacific hake Merluccius productus, and $K$. thyrsites in Atlantic salmon; Lom \& Dyková 1995, Moran et al. 1999c). 


\section{Identification of the Kudoa spore}

The parasite was readily assigned to the genus Kudoa based on the presence of 4 valves, each of which contained 1 polar capsule (Lom \& Dyková 1992). Within this genus, 44 species were recently recognized in a review by Moran et al. (1999c), and at least 2 additional species have subsequently been described (Pampoulie et al. 1999, Swearer \& Robertson 1999). Only 6 of the 46 species have spores ornamented with apical projections and uplifted tips to the valves: $K$. camarguensis, K. clupeidae, K. cynoglossi, K. kabatai, $K$. lunata, and $K$. miniauriculata. Although the shape of the spores is similar in the Atlantic menhaden parasite and $K$. camarguensis, the latter has valve tips elongated by tubular extensions, $2 \mu \mathrm{m} \times 0.5 \mu \mathrm{m}$ (Pampoulie et al. 1999). Shape of the spores distinguished the Atlantic menhaden parasite from $K$. cynoglossi, $K$. kabatai, and K. lunata, all of which are stellate in apical view (Kovaleva et al. 1979, Lom et al. 1983, Obiekezie \& Lick 1994). Variations in surface ornamentation further distinguished the menhaden parasite from $K$. kabatai, which bears posterio-lateral processes (Kovaleva et al. 1979). The spores from the Atlantic menhaden closely resembled $K$. miniauriculata, described from the somatic muscle of boccacio Sebastes paucispinis from California. In addition to very similar surface ultrastructure, spores from menhaden and boccacio both had crescent-shaped structures cupping the polar capsules; we identified these as capsulogenic nuclei in the Atlantic menhaden parasite, although Whitaker et al. (1996) identified them as 'remnants of capsulogenic cells.' The spores of $K$. clupeidae and $K$. miniauriculata, however, could be distinguished by size ( $K$. miniauriculata is wider), different sized apical projections (larger in the Atlantic menhaden parasites), and different-sized polar capsules (larger in K. miniauriculata) (Whitaker et al. 1996).

Morphology and morphometrics of the parasite we observed in Atlantic menhaden were consistent with Kudoa clupeidae spores previously described by Meglitsch (1947). Despite the limited light microscopy techniques available at that time, his remarkably meticulous study included descriptions of many of the features that we have elucidated using a comprehensive suite of stains and ultrastructural analyses. The 'rounded, rather flaring prominences' on the anterolateral surface described by Meglitsch are now recognized as uplifted tips to the valves. His description of the 10 nuclei giving the '(Heidenhain) stained spores a most unusual and distinctive appearance' was of particular taxonomic value. He reported 4 valvogenic nuclei as dark, flattened bodies lying against the spore membrane between the polar capsules and degenerating as the spores aged. Meglitsch described the capsulogenic nuclei as persistent and conspicuous 'flattened, usually crescentric bodies at the posterior margin of the capsules, quite large and striking.' With protargol silver protein impregnation, we were able to clearly show the crescent-shaped nuclei lying around the base and extending partly up the sides of the polar capsules (Fig. 5F), and with PAS we recognized an additional detail, namely an inner dense region within the crescent, lying at the base of the polar capsules (Fig. 5E). Transmission electron microscopy provided further details of these distinct nuclei: the crescent-shaped area appeared mottled, and within it, the electron-dense region was cleaved and tri-lobed (Figs. 3A \& 4). In both the study by Meglitsch (1947) and the one now presented, 2 nuclei were observed in the sporoplasm. We suggest that use of protargol silver protein impregnation and PAS can be used to improve diagnosis of the spores of this species of Kudoa, via staining of the characteristic nuclei.

No previous studies of surface or internal ultrastructure of Kudoa clupeidae are known. Thus, we have been able to describe some new features of the spore: the presence of 4 small apical projections, the structure of the capsulogenic nuclei, and the presence of numerous branching filamentous projections on the external surface of the capsulogenic cells. Although numerous (some 46) species of Kudoa are known, internal ultrastructure of the spore has been described for relatively few species. Of the 5 Kudoa species having similar morphology to the Atlantic menhaden parasite, namely spores with apical projections and uplifted tips to the valves, internal ultrastructure of the spore has been described for only a single species, $K$. lunata (Lom \& Dyková 1988). K. clupeidae is distinguished ultrastructurally from $K$. lunata by aspects of the valves and the capsulogenic cells. In $K$. clupeidae, the apical projections lack the numerous microtubules seen in $K$. lunata; furthermore, in K. clupeidae, the capsulogenic cells have crescent-shaped regions, electron-dense inclusions, and a surface covered by branching filamentous projections, none of which are seen in $K$. lunata (Lom \& Dyková 1988).

Previous studies and our present research have shown that species of Kudoa having spores that appear similar at the light microscopy level can be further distinguished by use of electron microscopy to visualize their surface and internal ultrastructure. We recommend that future studies of Kudoa spores include comprehensive ultrastructural analysis. However, even with such an approach, some spores may still appear very similar (such as those of $K$. miniauriculata and $K$. clupeidae). Molecular approaches, including partial sequencing of the genomic DNA encoding the small subunit (SSU) rRNA and development of specific PCR tests (as have been used successfully for spores of other 
Kudoa species [Hervio et al. 1997]), are warranted for spores of $K$. clupeidae. Improved characterization and recognition of species will facilitate more accurate host and geographic range records.

\section{Previous record of Kudoa clupeidae}

The literature indicates a wide host and geographic range for Kudoa clupeidae spores, from clupeids to scombrids, and from the Atlantic to the Pacific Oceans. Among the more detailed and reliable reports are those describing infections in clupeids from the east coast of the USA by Hahn (1917), who reported the parasite as Chloromyxum clupeidae, by Meglitsch (1947), who transferred the parasite to the genus Kudoa, and by Sindermann \& Rosenfield (1954). From these papers we learn that $K$. clupeidae infects alewife from Massachusetts, Atlantic herring from Maine and Massachusetts, blueback herring from Massachusetts, and Atlantic menhaden from North Carolina. Thus, although the present report indicates a new geographic record for $\mathrm{K}$. clupeidae, the location of the Chesapeake Bay lies within the geographic range along the Atlantic coast of the US previously reported for this parasite.

Parasites resembling Kudoa clupeidae have also been reported in carangid fish from Moroccan waters (Balozet 1930); scombrids from Australia, the Atlantic coast of the USA, and the west coast of Africa (Williams \& Bunkley-Williams 1996); and in clupeid, labrid, sparid and zoarcid fishes from the Atlantic coast of the USA (Tyzzer 1900, Linton 1901, Nigrelli 1946). The parasites reported in these publications require detailed redescriptions in order to confirm their identities. Reports of K. clupeidae in rockfish (Scorpaenidae) from the Pacific coast of the USA (Moser et al. 1976, Heckmann \& Jensen 1978) were considered incorrect by Whitaker et al. (1996), who believed that the parasites are most likely Kudoa miniauriculata.

It is not known which of the ca. 300 fish species that inhabit Chesapeake Bay, one of the largest estuaries in the world, may also be infected with Kudoa clupeidae. Some of the more commercially important fishes in the Chesapeake Bay are known to carry Kudoa sp. (Paperna \& Zwerner 1974, Bunton \& Poynton 1991), but to the best of our knowledge, none of these parasites has been identified as $K$. clupeidae.

\section{Kudoa clupeidae development in Atlantic menhaden}

It is important to note that mature Kudoa clupeidae spores were identified in Atlantic menhaden during April and May, when the fish are approximately 3 to 4 mo old. This indicates that infection, development, and spore maturation occurs within the first few months of life. A number of myxozoan parasites have been shown to infect primarily young fishes, especially in spring and early summer (Kent et al. 1994, Rothwell et al. 1997, Holzer \& Schachner 2001). Other examples of myxosporean infections of young fishes include proliferative kidney disease in trout, whereby the fish are infected during April and May (Foote \& Hedrick 1987), Sphaerospora truttae in salmon (Ozer \& Wootten 2000), Myxobolus cerebralis infection in the rainbow trout Oncorhynchus mykiss (Markiw 1991), Myxobolus episquamalis infection in the sea mullet Mugil cephalus in the spring (Rothwell et al. 1997), and Kudoa thyrsites infection in Atlantic salmon (St-Hilaire et al. 1998).

Temperature can affect the development, release and longevity of the parasite in an intermediate (or alternate) host (El-Matbouli et al. 1999), as well as the development of the fish host. In the case of Myxobolus cerebralis, numbers of triactinomyxon spores are highest in the spring when water temperatures are 15 to $16^{\circ} \mathrm{C}$, the same period when rainbow trout fry are at their most susceptible age for infection (Markiw 1991, 1992, Kent et al. 2001). Immune status of young fish may be an additional factor. Holzer \& Schachner (2001) state that 'huge masses of myxosporidian developmental stages are usually conspicuous only in immature diseased fish which have not yet acquired immunity.' Moran \& Kent (1999) suggest that compromised immunity during prolonged periods of stress (such as smoltification and sexual maturation) permit the parasite to proliferate and/or reinfect fishes.

The time course from exposure to the formation of spores varies among myxozoan parasites. Some of the variation may be due to the influence of temperature on either the host, the parasite, or both. In the case of Myxobolus cerebralis, signs of disease and spores were identified in rainbow trout fry approximately $90 \mathrm{~d}$ postexposure (p.e.) (Wolf \& Markiw 1984, El-Matbouli \& Hoffman 1989). Yokoyama et al. (1995) found mature spores of $M$. cultus in goldfish (Carassius auratus) fry as early as 2 mo p.e. In the case of Ceratomyxa shasta infections, spores are present in rainbow trout (Shasta strain) approximately 40 d p.e. (Bartholomew et al. 1997). In contrast, Kudoa thyrsites requires approximately 5 to 6 mo to develop spores in Atlantic salmon (Moran \& Kent 1999, Moran et al. 1999b,c). Using K. thyrsites-specific PCR primers, however, infection could be documented as early as 6 wk p.e. (Moran et al.1999a). Shaw et al. (1997) found extensive infections of $K$. thyrsites in adult tube-snout Aulorhynchus flavidus, but also detected the organism in fish less than 4 mo old using PCR primers specific for $K$. thyrsites. Those fish had no other apparent sign of infection. For mature $K$. clupeidae to be present in 3 to 4 mo old Atlantic menhaden, the infective stage of 
the parasite, the actinosporean, would have to infect the fish when they are quite young, probably 2 to 3 mo old at most.

Despite many recent advances in our understanding of the life cycle of myxosporeans (Kent et al. 2001), most notably that some species have a 2-host life cycle with a myxosporean stage in the fish host and an actinosporean stage in an invertebrate host, the life cycle is not known for any species of Kudoa (El-Matbouli et al. 1992, Lom \& Dyková 1992, Kent et al. 2001). Recently, Moran et al. (1999c) determined that $K$. thyrsites, an infection of cultured salmonids in the Pacific northwest, does produce extrasporogonic stages that are transmissible by injection of blood from infected fish into the peritoneum of naïve fish. They were, however, unable to transmit the infections using fresh myxospores in direct transmission experiments. This suggests that, like many other myxozoan parasites of fishes, an alternate host is necessary for $K$. thyrsites. If an alternate host does exist for $K$. clupeidae, infection in Atlantic menhaden must begin at least as early as 2 to 3 mo of age, since mature spores are found in fish approximately 3 to 4 mo of age. Molecular studies, such as those conducted by Shaw et al. (1997) and Moran et al. (1999a), will be needed to determine how early these fish become infected. The search for an alternate stage (i.e. actinospore) and alternate host could then begin in locales where the juveniles are located at that period of life.

In contrast to the 2-host life cycles reported for some freshwater myxoporeans, direct transmission has recently been suggested for Kudoa ovivora, a parasite of caribbean labroid fishes (Swearer \& Robertson 1999). Furthermore, fish-to-fish transmission of Myxidium leei was experimentally demonstrated in the sea bream Sparus auratus by Diamant (1997), who suggested such direct transmission may be a model for the development of other marine myxosporeans. The estuarine origins of $K$. clupeidae may offer some insight into the diversity of life cycles with varying salinity.

It is interesting to note that the mature spores are found in fish caught earlier in the spring and the invasive plasmodia are found in fish caught about 1 to $2 \mathrm{wk}$ later. The latter fish also have heavy Kudoa clupeidae infections in their muscles. This timing may indicate that the myxozoan is undergoing a massive proliferation (extrasporogonic), similar to that described for PKX and Sphaerospora spp. (Lom \& Dyková 1992, Kent et al. 2001), at the same time that other plasmodia are progressing with spore formation.

\section{Other parasites}

Most of the parasites we observed as incidental findings were also myxosporeans. The amoeboid or plas- modial organisms attached to the microvilli of the lower gastrointestinal tract appear to be trophic stages of a myxosporean with cytoplasmic holdfasts or moving pseudopodia, similar to those known for some coelozoic trophozoites (such as Zschokkella costata, which attaches by finger-like pseudopodia to the epithelium of the urinary duct of the roach Rutilus rutilus) (Lom \& Dyková 1992). We are unable to comment upon the possible relationship of Kudoa clupeidae to either the intestinal parasite or to the kidney myxozoan because the ultrastructure of those parasites was not studied. Our observations of Myxobolus sp. in the gills, buccal cavity and fins of Atlantic menhaden appears to be the first report of this parasite in this fish species. The most recent check list of parasites of menhaden (Reintjes 1969) lists only 1 myxosporean, Chloromyxum clupeidae (syn. K. clupeidae).

\section{Conclusion}

Our findings indicate a clear seasonal occurrence of lesions caused by invasive developmental myxosporean plasmodia in young-of-the-year Atlantic menhaden. These fish also had abundant mature Kudoa clupeidae spores in the musculature. This study clearly demonstrates that gross observations alone are inadequate for establishing the cause of lesions. It is essential to conduct careful histopathological examination of lesions to define the etiology. In order to confirm our hypothesis that the developmental plasmodia seen in the lesions are, indeed, $K$. clupeidae, further studies using transmission experiments and molecular techniques, such as cDNA comparisons, are necessary.

Acknowledgements. We extend our thanks to Harley Speir and Dr. Steve Jordan for the design of the field sampling strategy, to Brett Coakley, Brenda Kibler, and Larry Pieper for their diligent collection of the field samples, and to John Jacobs, Harry Rickabaugh, and Keith Whiteford for the specimens and data from their related projects. We are grateful to Carol McCollough, Jud Blazek, and Sue Tyler for their meticulous preparation of the histology samples, and to Seung Chang and Maritza Patton for their scrupulous assistance with sample processing for scanning and transmission electron microscopy. We also thank Perry Comegys for excellent processing of the photomicrographs, and Debbie Brooks for assistance with our literature searches.

\section{LITERATURE CITED}

Ahrenholz DW, Guthrie JF, Clayton RM (1987) Observations of ulcerative mycosis infections on Atlantic menhaden (Brevoortia tyrannus). NOAA Tech Memo NMFS SEFC196:1-10

Balozet L (1930) Myxosporidie d'un poisson Marocain. Bull Soc Sci Nat Phys Maroc 9:203-207 
Bartholomew JL, Whipple MJ, Stevens DG, Fryer JL (1997) The life cycle of Ceratomyxa shasta, a myxosporean parasite of salmonids, requires a freshwater polychaete as an alternate host. J Parasitol 83:859-868

Baya AM, Lupiani B, Hetrick FM, Roberson BS, Lukacovic R, May E, Poukish C (1990) Association of Streptococcus spp. with fish mortalities in the Chesapeake Bay and its tributaries. J Fish Dis 13:251-253

Baya AM, Romalde JL, Green DE, Navarro RB, Evans JJ, May E, Toranzo AE (1997) First epizootic of Edwardsiellosis in wild striped bass in the Chesapeake Bay. J Wildl Dis 33: 517-525

Bennett HS, Luft JH (1959) S-collidine buffer as a basis for buffering fixatives. J Biophys Biochem Cytol 6:113-114

Blazer VS, Vogelbein WK, Densmore CL, May EB, Lilley JH, Zwerner DE (1999) Aphanomyces as a cause of ulcerative skin lesions of menhaden from Chesapeake Bay tributaries. J Aquat Anim Health 11:340-349

Blazer VS, Lilley JH, Schill WB, Kiryu Y, Densmore CL, Panyawachira V, Chinabut S (2002) Aphanomyces invadans in Atlantic menhaden along the east coast of the United States. J Aquat Anim Health (in press)

Bunton TE, Poynton SL (1991) Kudoa sp. (Myxosporea, Multivalvulida) in juvenile white perch, Morone americana (Gmelin): histopathology and spore morphology. J Fish Dis 14:589-594

Burkholder JM, Glasgow HB (1997) Pfiesteria piscicida and other Pfiesteria-like dinoflagellates: behavior, impacts, and environmental controls. Mar Ecol Prog Ser 124:43-61

Carson FL (1990) Histotechnology: a self-instructional text, 2nd edn. American Society of Clinical Pathologists, Chicago

CDC (Center for Disease Control \& Presentation) (1997) Notice to readers: results of the public health response to Pfiesteria workshop, Atlanta, Georgia, September 29-30. Morb Mortal Wkly Rep 46:951-952

Cloney RA, Florey E (1968) Ultrastructure of cephalopod chromatophore organs. Z Zellforsch Mikrosk Anat 89: 250-280

Diamant A (1997) Fish to fish transmission of a marine myxosporean. Dis Aquat Org 30:99-105

Dungan C, Elston R (1988) Histopathological and ultrastructural characteristics of bacterial destruction of the hinge ligaments of cultured juvenile Pacific oysters, Crassostrea gigas. Aquaculture 72:1-14

Dykstra MJ, Noga EJ, Levine JF, Moye DW, Hawkins JH (1986) Characterization of the Aphanomyces species involved in ulcerative mycosis (UM) in menhaden. Mycologia 78:664-672

Dykstra MJ, Levine JF, Noga EJ, Hawkins JH, Gerdes P, Hargis WJ, Grier HJ, Te Strake D (1989) Ulcerative mycosis: a serious menhaden disease of the south-eastern coastal fisheries of the United States. J Fish Dis 12:175-178

Egusa S (1986) The order Multivalvulida (Shulman, 1959) (Myxozoa; Myxosporea): a review. Fish Pathol 21:261-274 (in Japanese)

El-Matbouli M, Hoffmann R (1989) Experimental transmission of two Myxobolus spp. developing bisporogeny via tubificid worms. Parasitol Res 75:461-464

El-Matbouli M, Fisher-Scherl T, Hoffmann RW (1992) Present knowledge on the life cycle, taxonomy, pathology and therapy of some Myxosporea spp. important for freshwater fish. Annu Rev Fish Dis 2:367-402

El-Matbouli M, McDowell TS, Antonio DB, Andree KB, Hedrick RP (1999) Effect of water temperature on the development, release and survival of the triactinomyxon stage of Myxobolus cerebralis, the causative agent of whirling disease, in its oligochaete host. Int J Parasitol 29: 627-641

Farquhar MG, Palade GE (1965) Cell junctions in amphibian skin. J Cell Biol 26:263-291

Foote JS, Hedrick RP (1987) Seasonal occurrence of the infectious stage of proliferative kidney disease and resistance of rainbow trout, Salmo gairdneri Richardson, to reinfection. J Fish Biol 30:477-483

Frasca S, Poynton SL, West AB, van Kruiningen (1998) Epizootiology, pathology, and ultrastructure of the myxosporean associated with parasitic encephalitis of farmed Atlantic salmon Salmo salar in Ireland. Dis Aquat Org 32: $211-225$

Frasca S, Linfert DR, Tsongalis GJ, Gorton TS, Garmendia AE, Hedrick RP, West AB, van Kruiningen HJ (1999) Molecular characterization of the myxosporean associated with parasitic encephalitis of farmed Atlantic salmon Salmo salar in Ireland. Dis Aquat Org 35:221-233

Friedrich C, Ingolic E, Freitag B, Kastberger G, Homann V, Skofitsch G, Neumeister U, Kepka O (2000) A myxozoanlike parasite causing xenomas in the brain of the mole, Talpa europaea L., 1758 (Vertebrata, Mammalia). J Parasitol 121:483-492

Hahn CW (1917) On the sporozoan parasites of the fishes of Woods Hole and vicinity. III. On the Chloromyxum clupeidae of Clupea harengus (Young), Pomolobus pseudoharengus (Young), and P. aestivalis (Young). J Parasitol 4: $13-20$

Hale MB, Bauersfeld PE, Galloway SB, Joseph JD (1991) New products and markets for menhaden Brevoortia spp. Mar Fish Rev 53:42-48

Heckmann RA, Jensen LA (1978) The histopathology and prevalence of Henneguya sebasta and Kudoa clupeidae in the rockfish, Sebastes paucispinis of Southern California. J Wildl Dis 14:259-262

Hervio DML, Kent ML, Khattra J, Sakanari J, Yokoyama H, Devlin RH (1997) Taxonomy of Kudoa species (Myxosporea), using a small-subunit ribosomal DNA sequence. Can J Zool 75:2112-2119

Holzer AS, Schachner O (2001) Myxosporidia and macrophage centers in chub (Leuciscus cephalus) - quantitative interactions focus on Myxobolus cyprini. Parasitology 122: $55-62$

Huxley HE, Zubay G (1961) Preferential staining of nucleic acid-containing structures for electron microscopy. J Biophys Biochem Cytol 11:273-296

Kane AS, Oldach D, Reimschuessel R (1998) Fish lesions in the Chesapeake Bay: Pfiesteria-like dinoflagellates and other etiologies. MD Med J 47:106-112

Kane AS, Dykstra MJ, Noga EJ, Reimschuessel R, Baya A, Driscoll C, Paerl HW, Landsberg J (2000) Etiologies, observations and reporting of estuarine fish lesions. Mar Environ Res 50:473-477

Kent ML, Margolis L, Whitaker DJ, Hoskins GE, McDonald TE (1994) Review of Myxosporea of importance in salmonid fisheries and aquaculture in British Columbia. Folia Parasitol (České Budějovice) 41:27-37

Kent ML, Andree KB, Bartholomew JL, El-Matbouli M and 12 others (2001) Recent advances in our knowledge of the Myxozoa. J Eukaryot Microbiol 48:395-413

Kiryu Y, Shields J, Vogelbein WK, Zwerner DE, Kator H, Blazer VS (2003) Induction of skin ulcers in Atlantic menhaden by injection and water-borne exposure to the zoospores of Aphanomyces invadans. J Aquat Anim Health (in press)

Kovaleva AA, Schulman SS, Yakovlev VN (1979) Myxosporidia of the genus Kudoa (Myxosporidia, Multi- 
valvulea) from the basin of the Atlantic Ocean. Tr Zool Inst Akad Nauk SSSR 87:42-64 (in Russian)

Levine JF, Hawkins JH, Dykstra MJ, Noga EJ, Moye DW, Cone RS (1990a) Species distribution of ulcerative lesions on fin fish in the Tar-Pamlico River Estuary, North Carolina. Dis Aquat Org 8:1-5

Levine JF, Hawkins JH, Dykstra MJ, Noga EJ, Moye DW, Cone RS (1990b) Epidemiology of ulcerative mycosis in Atlantic menhaden in the Tar-Pamlico River Estuary, North Carolina. J Aquat Anim Health 2:162-171

Lilley JH, Callinan RB, Chinabut S, Kanchanakhan S, MacRae, IH, Phillips MJ (1998) Epizootic ulcerative syndrome technical handbook. The Aquatic Animal Health Research Institute, Bangkok

Linton E (1901) Parasites of fishes of the Woods Hole region. Bull US Fish Comm 19:407-492

Lom J, Arthur JR (1989) A guideline for the preparation of species descriptions in Myxosporea. J Fish Dis 12:151-156

Lom J, Dyková I (1988) Sporogenesis and spore structure in Kudoa lunata (Myxosporea, Multivalvulida). Parasitol Res 74:521-530

Lom J, Dyková I (1992) Protozoan parasites of fishes. Elsevier, Amsterdam

Lom J, Dyková I (1995) Myxosporea (Phylum Myxozoa). In: Woo PTK (ed) Fish diseases and disorders, Vol 1. Protozoan and metazoan infections. CAB International, Wallingford, p 97-148

Lom J, Dyková I, Lhotáková S (1983) Kudoa lunata n.sp. (Myxozoa, Myxosporea) and notes on the nature of muscular 'cysts' of the genus Kudoa. Arch Protistenkd 127: 387-397

Luft JH (1961) Improvements in epoxy embedding methods. J Biophys Biochem Cytol 9:409-414

Markiw ME (1991) Whirling disease: earliest susceptible age of rainbow trout to the triactinomyxon of Myxobolus cerebralis. Aquaculture 92:1-6

Markiw ME (1992) Experimentally induced whirling disease. I. Dose response of fry and adults of rainbow trout exposed to the triactinomyxon stage of Myxobolus cerebralis. J Aquat Anim Health 4:40-43

Marty GD, Freiberg EF, Meyers TR, Wilcock J, Farver TB, Hinton D (1998) Viral hemorrhagic septicemia virus, Ichthyophonus hoferi, and other causes of morbidity in Pacific herring Clupea pallasi spawning in Prince William Sound, Alaska, USA. Dis Aquat Org 32:15-40

Meglitsch PA (1947) Studies on Myxosporidia from the Beaufort Region. II. Observations on Kudoa clupeidae (Hahn), gen. nov. J Parasitol 33:271-277

Moran JDW, Kent ML (1999) Kudoa thyrsites (Myxozoa: Myxosporea) infections in pen-reared Atlantic salmon in the eastern North Pacific Ocean, with a survey of potential nonsalmonid reservoir hosts. J Aquat Anim Health 11: 101-109

Moran JDW, Margolis L, Webster JM, Kent ML (1999a) Development of Kudoa thyrsites (Myxozoa: Myxosporea) in netpen-reared Atlantic salmon determined by light microscopy and a polymerase chain reaction test. Dis Aquat Org 37:185-193

Moran JDW, Whitaker DJ, Kent ML (1999b) Natural and laboratory transmission of the marine myxosporean parasite Kudoa thyrsites (Gilchrist, 1924) to Atlantic salmon. J Aquat Anim Health 11:110-115

Moran JDW, Whitaker DJ, Kent ML (1999c) A review of the myxosporean genus Kudoa Meglitsch, 1947, and its impact on the international aquaculture industry and commercial fisheries. Aquaculture 172:163-196

Moser M, Love MS, Jensen LA (1976) Myxosporidia (Proto- zoa) in California rockfish, Sebastes spp. J Parasitol 62: 690-692

Nigrelli RF (1946) Studies on the marine resources of southern New England. V. Parasites and diseases of the ocean pout, Macrozoarces americanus. Bull Bingham Oceanogr Collect Yale Univ 9:187-221

Noga EJ (2000) Skin ulcers in fish: Pfiesteria and other etiologies. Toxicol Pathol 28:807-823

Noga EJ, Dykstra MJ (1986) Oomycete fungi associated with ulcerative mycosis in Atlantic menhaden. J Fish Dis 9: 47-53

Noga EJ, Khoo L, Stevens JB, Fan Z, Burkholder JM (1996) Novel toxic dinoflagellate causes epidemic disease in estuarine fish. Mar Pollut Bull 32:219-224

Obiekezie AI, Lick R (1994) Kudoa Cynoglossi n.sp., a new species of Kudoa Meglitsch (Myxoporea: Multivalvulida) from the West Africa tongue sole, Cynoglossus senegalensis (Kaup) (Teleostei: Cynoglossidae). Arch Protistenkd 144:201-205

Ozer A, Wootten R (2000) The life cycle of Sphaerospora truttae (Myxozoa: Myxosporea) and some features of the biology of both the actinosporean and myxosporean stages. Dis Aquat Org 40:33-39

Pampoulie C, Marques A, Rosecchi E, Crivelli AJ, Bouchereau JL (1999) A new myxosporean parasite, Kudoa camarguensis n. sp., recorded on two goby species (Teleostei: Pices) in the Rhone Delta (Mediterranean Sea, France). J Eukaryot Microbiol 46:304-310.

Paperna I, Zwerner DE (1974) Kudoa cerebralis sp.n. (Myxosporidea, Chloromyxidae) from the striped bass, Morone saxatilis (Walbaum). J Protozool 21:15-19

Pote LM, Hanson LA, Shivaji R ( 2000) Small subunit ribosomal RNA sequences link the cause of proliferative gill disease in channel catfish to Henneguya n. sp. (Myxozoa: Myxosporea). J Aquat Anim Health 12:230-240

Prophet EB, Mills B, Arrington JB, Sobin LH (eds.) (1992) Laboratory methods in histotechnology. American Registry of Pathology, Armed Forces Institute of Pathology, Washington, DC, p 25-226

Reintjes (1969) Synopsis of biological data on the Atlantic menhaden, Brevoortia tyrannus. FAO Species Synopsis No 42, Circular 320. US Department of the Interior, Washington, DC

Rogers SG, van den Avyle MJ (1989) Species profiles: life histories and environmental requirements of coastal fishes and invertebrates (Mid-Atlantic) Atlantic menhaden. US Fish Wild Ser Biol Rep 82(11.108) TREL-82-4:1-23

Rothwell JT, Virgona JL, Callinan RB, Nicholls PJ, Langdon JS (1997) Occurrence of cutaneous infections of Myxobolus episquamalis (Myxozoa:Myxobolidae) in sea mullet, Mugil cephalus L, in Australia. Aust Vet J 75:349-352

Schäperclaus W (1991) Fish diseases, Vol 2. AkademieVerlag, Berlin, 1986. Translation by Amerind Publishing, New Delhi

Shaw RW, Hervio DML, Devlin RH, Adamson ML (1997) Infection of Aulorhynchus flavidus (Gill) (Osteichthyes: Gasterosteiformes) by Kudoa thyrsites (Gilchrist) (Myxosporea: Multivalvulida). J Parasitol 83:810-814

Sheehan DC, Hrapchak BB (1980) Theory and practice of histotechnology, 2nd edn. Battelle Press, Columbus, $\mathrm{OH}$

Sindermann CJ (1988) Epizootic ulcerative syndromes in coastal/estuarine fish. NOAA Tech Mem NMFSF/NEC$54: 1-37$

Sindermann CJ (1990) Principal diseases of marine fish and shellfish, 2nd edn, Vol 1. Diseases of marine fish. Academic Press, New York

Sindermann CJ, Rosenfield A (1954) Diseases of fishes of the 
Western North Atlantic. I. Diseases of the sea herring (Clupea harengus). Res Bull, Dept Sea Shore Fish, ME 18:1-23 Smith JW (1991) The Atlantic and Gulf menhaden purse seine fisheries: origins, harvesting technologies, biostatistical monitoring, recent trends in fisheries statistics, and forecasting. Mar Fish Rev 53:28-41

Smith JW (1999) Distribution of Atlantic menhaden, Brevoortia tyrannus, purse-seine sets and catches from southern New England to North Carolina, 1985-1996. NOAA Tech Rep NMFS 144:1-22

Stehr C, Whitaker DJ (1986) Host-parasite interaction of the myxosporeans Kudoa paniformis Kabata \& Whitaker 1981 and Kudoa thyrsites (Gilchrist 1924) in the muscle of Pacific whiting, Merluccius productus (Ayres): an ultrastructural study. J Fish Dis 9:505-517

St-Hilaire S, Ribble C, Whitaker DJ, Kent ML (1998) Prevalence of Kudoa thyristes in sexually mature and immature pen-reared Atlantic salmon (Salmo salar) in British Columbia, Canada. Aquaculture 162:69-77

Swearer SE, Robertson DR (1999) Life history, pathology and description of Kudoa ovivora n.sp. (Myxozoa, Myxosporea): an ovarian parasite of Caribbean labroid fishes. J Parasitol 85:337-353

Te Strake D, Lim DV (1987) Bacterial and fungal studies of ulcerative fish in the St. Johns River. Reg Contract Rep WM 138. Florida Department of the Environment, Tampa, p 1-34

Trump BF, Smucker EA, Bennett EP (1961) A method for staining Epoxy sections for light microscopy. J Ultrastruct Res 5:343-348

Editorial responsibility: Wolfgang Körting,

Hannover, Germany
Tyzzer EE (1900) Tumors and sporozoa in fishes. J Boston Soc Med Sci 5:62-68

US Food \& Drug Administration (1997) 21 CFR Part 184 Substances affirmed as generally recognized as safe: menhaden oil. Fedl Register 62:30751-30757

Uspenskaya AV (1981) Investigations of ultrastructure and cytochemical peculiarities of Kudoa quadratum (Thelohan 1895) (Myxosporidia, Multivalvulea). In: Simpozium po parazitologii I patologii morskikh organizmov. Leningrad, USSR, 13-16 okt. Nauka, Leningrad, p 107-108 (in Russian)

Venable JH, Coggeshall R (1965) A simplified lead citrate stain for use in electron microscopy. J Cell Biol 2:407-498

Whitaker DJ, Kent ML, Sakanari JA (1996) Kudoa miniauriculata n.sp. (Myxozoa, Myxosporea) from the musculature of bocaccio (Sebastes paucispinis) from California. J Parasitol 82:312- 315

Williams EH, Bunkley-Williams L (1996) Parasites of offshore big game fishes of Puerto Rico and the western Atlantic. Puerto Rico Department of Natural and Environmental Resources, San Juan, Puerto Rico and the University of Puerto Rico, Mayaguez

Wolf K, Markiw M (1984) Biology contravenes taxonomy in the Myxozoa: new discoveries show alternation of invertebrate and vertebrate hosts. Science 225:1449-1452

Yokoyama H, Ogawa K, Wakabayashi H (1995) Myxobolus cultus n. sp. (Myxosporea: Myxobolidae) in the goldfish Carassius auratus transformed from the actinosporean stage in the oligochaete Branchiura sowerbyi. J Parasitol 81:446-451

Submitted: January 28, 2002; Accepted: August 10, 2002 Proofs received from author(s): January 21, 2003 